\title{
Physical earth and its sciences in Istanbul: a journey from pre-modern (Islamic) to modern times
}

\author{
Ferhat Ozcep ${ }^{1, a}$ \\ ${ }^{1}$ Department of Geophysical Engineering, İstanbul University-Cerrahpaşa, Istanbul, Turkey \\ ${ }^{a}$ visiting scholar at: Department of the History of Science, Harvard University, Cambridge, MA, USA
}

Correspondence: Ferhat Ozcep (ferozcep@istanbul.edu.tr)

Received: 18 April 2020 - Revised: 3 July 2020 - Accepted: 11 July 2020 - Published: 18 August 2020

\begin{abstract}
Researching, compiling and analysing geophysical ideas and measurements in historical periods will contribute to the historical development of earth science. Also, this is important for geophysicists working on time-dependent (historical) data and revealing the physical properties of the earth. This paper is focused on the earth and its sciences (with concepts, ideas and measurements) in classical Islamic science in the Ottoman Empire and the evolution of these thoughts and concepts in the context of the transition to modern science. The pre-modern period of science in Islamic geographies is represented by Aristotelian science and some original contributions. In the geophysical sciences of the Ottoman Empire, earthquakes and weather events are explained by his views and ideas. Modern concepts and scientific measurements of geophysical events such as magnetic, seismologic and meteorologic events were systematically begun by observatories. Before this, there are some individual measurements.
\end{abstract}

\section{Introduction and general remarks}

In the 16th century that term "modern" (from late Latin modernus and Latin modo, "just now") was coined and is related to the present or recent times as opposed to the remote past. New knowledge about the universe was discovered and explored by using empirical observation. In contrast to the modern era, "pre-modern" thought is represented via faith based on the historic use of reason and innate knowledge. Modernity as a term is not only used to designate a historical period but also to represent socio-cultural norms, attitudes and practices. Modernity as historical period denotes an era marked by a questioning or denial of tradition and includes many concepts and issues such as the ranking of individualism, freedom and formal equality; belief in unavoidable social, scientific and technological progress and human perfectibility; rationalization and professionalization; the market economy; industrialization, urbanization and secularization; and the development of the nation state and its constituent institutions (Foucault, 1995). As a methodical thought and normative ideal, modernity is connected to the character of philosophical and aesthetic modernism and po- litical and intellectual currents that intersect with the Enlightenment (Berman, 2010).

Istanbul has been given different names throughout the ages. These city names are related to different periods of urban history. The historic development of this city can be divided into five major periods: the prehistoric era, era of Byzantium, Eastern Roman period, Ottoman period and period of Turkey. Istanbul is a city that has been among the most important and biggest metropolises of the world for about 16 centuries from the 4th century to the 20th century. It has been a representative of a large region where the continents of Europe, Asia and Africa meet and has managed to influence world history significantly in this process. In this study we focused on the Ottoman period. Our study was based on the investigation of geophysical ideas and measurements in the Ottoman geography in transition from the pre-modern (Islamic) to the modern (Western) period. The pre-modern-modern dilemma along Islamic-Western cultures may be problematic. Another alternative for this context may be "Aristotelian science-Newtonian science". Before the Newtonian era, science in Islamic and Western geographies was mainly driven by Aristotelian science. This 
paper is a continuation of works by Ozcep and Ozcep (2014) and Ozcep (2018).

\section{Science in Islamic geographies}

This section will provide a broad view of the Islamic intellectual legacy for two reasons. (1) This is important for the transition period to understand the pre-modern and modern. (2) Earth science in Ottoman geographies is a new field of research, and many topics related to this are unknown in the integrated context. Because of these reasons, it was necessary to be explained on a large scale.

\subsection{Pre-Ottoman period of science in Islam}

The Orkhon inscriptions that were written about the legendary origins of the Turks were erected in the Orkhon Valley in Mongolia in the early eight century by the Göktürks. A naturalistic belief among ancient Turks is explained as Yer$S u b$ (earth water) in Orkhon inscriptions, and earth water is $i d u k$, in other words, sacred. The representation of the earth waters in the history of the Turkish religion is as mountains. The cult of mountains is related to the faith in a sky god. The term Yer-Su implies that trees, fire and water, the earth, rocks, and stones have a sacred meaning and importance. As an example, in the Orkhon inscriptions "blue sky" and "black earth" form two main cosmic fields and complement each other. The creation of God in the legends is not in the form of creation from nothing, but it is rather in the creation from pre-existing matter (Gungor, 2002).

"Science" is directly translated as ilm (plural al-ulum) in Arabic (Greenham, 2016). On the other hand, ilm was the Arabic translation of Greek episteme and was translated into Latin as scientia. But scientia and episteme mean also knowledge or learning in general and do not equate to modern science. For example, Ilm ul Nucum ("knowledge of stars") could be translated as the science of stars. Ilm was not limited to knowledge of the natural world, as it also referred to religious learning, law or history (Yücesoy, 2009). Initial interest in science in Islam originated from a concern with pragmatic art and sciences such as medicine, astronomy and chemistry (Henry, 2012). According to Bakar (1996) science is covered traditionally as (1) mathematical sciences (Ulum al Ta'alim of Al-Ulum-Riyadiyah) and (2) natural sciences (al ulum al tabiiyah) including physical sciences, biological sciences and cognitive sciences. Philosophy and science in Islamic geographies are the product of a complex intellectual process in which Syrians, Arabs, Persians, Turks, Berbers and others took an active part (Fakhry, 1983). The concept of the universe in the Quran is conveyed by the phrase "the Heavens and the Earth" and whatever lies between them (Daud, 1989). During the Islamic period of science, there were many scholars who at different times increased the knowledge about natural process on the earth's surface (Al-Ravi, 2014). In the Quran, the term al-Ard (or
$A r z)$ is not only the planet Earth but the entire inorganic universe including the planet Earth (Daud, 1989). In the Quran, "earth" refers both to the terrestrial part of the universe including all materials and the human body (anatomy). In both cases the Arabic word Ard (Arz) is used (over 450 occurrences). Primarily Ard denoted the earth in distinction to the heavenly sky. This is the case in many verses in which the paired couplet "heaven and earth" (al-sema wal ard) or heavens and the earth (al semawat wa-l-ard) are used. Secondly Ard denotes the space assigned to humankind and the earth's animals (Toelle, 2001). The earth was considered to have a special position in the universe. Special attention was paid to the formation of rocks and mountains and the course of rivers, natural process, minerals and lapidaries (Iqbal, 2007). As Noyan (2014) points out, the "study of natural sciences in Islamic world was the product of a religious culture that regarded the earth as a garden created by God for human beings to live in discover and protect". Knowledge in Arabic that is conveyed through the terms al-Ilm, al-Marifa and al-Shuur (awareness) is of the highest importance because it is one of the divine attributes (Daud, 1989). In the Quran, natural phenomena are signs (Ayet) of the existence and nature of God (16:66, 41:53, 51:20-21, 88:17-20) and the world organizing a direction (3:191, 21:16, 38:27). Modern defenders of Islamic science argue that both Islam and natural science rest on an attitude toward rationality (Leaman, 2009). As Campanini (2004) points out, "Stretching from Morocco to the Indus, and from steps of central Asia to the Persian Gulf, Islam unified widely different geographical regions and cultures by means of a religious message revealed to the Prophet Mohammed". Muslim scientists in Islamic geographies did not consider geology as a separate science with scopes and limits, but they discussed various aspects of subjects and related topics in their writings such as the origin and formation of the earth, its structure, geomorphology, the formation of seas, land, earthquakes, etc. (Ahmad and Baipakov, 2000). Earth sciences are important to Muslim scholars for two reasons: (1) it was a branch of science to which attention was directed by the Quran, and (2) it was practically useful, and all that taken as a sign of God (Iqbal, 2007). Muslim cosmological and natural sciences are closely related to the metaphysical, religious and philosophical ideas guided Islamic civilizations (Nasr, 1964). In Islamic cosmology God is the first being and creator of the universe and everything in the earth and sky and the one who formed them, the builder of order (Ihsanoğlu and Ayduz, 2002).

Harun al-Rashid (caliph of Islam from 786 to his death) was the patron of science, art and literature. Many more Greek works were translated by his order (Sarton, 1927).

As George Sarton pointed out:

The ninth century was essentially a Muslim century, to be sure, intellectual work did not cease... Activities of Muslim scholar was overwhelmingly superior. They were superiors in almost every re- 
spect... Consider only first half of century, leading men of science, Al-Kindi, Al-Kharizmi, AlFarghani were all Muslim...

Related to geography, two "pillars" of the Muslim faith help clarify deep interest (Kish, 1978): (1) Muslims are admonished to pray at certain times of day, turning toward the holy city of Mecca. For this reason, a special niche exists in every mosque to indicate to the faithful the direction of Mecca. (2) During one's lifetime every Muslim is expected to accomplish the Hajj or pilgrimage to Mecca. Linked with geography and geodesy, Al-Mamun (786-833) ordered geodetic measurements to determine the size of the earth and drawing of a large map of the world (Sarton, 1927).

Al-Biruni (973, after 1050), as Sarton (1927) points out, was one of the very greatest scientists of Islam, and all considered one of the greatest of all time. Al-Biruni has a book entitled Tahdit-al-Amakin (On Determination of Geographic Coordinates of Places). In this book Al-Biruni explains some descriptive passages related to geodesy. In this book, there are some remarks on the physical geography of past, on the creation, on water, on the relations between the distribution of the population and on the shape of the earth (Kish, 1978). Al-Biruni paid special attention to mineralogy in his Kitab al-Jamahir fi Marifet al-Jawahir (Ahmad and Baipakov, 2000). He also made investigations on the specific gravity of solid of irregular shapes (estimations on density of 18 precious stones and metals) (Sarton, 1927; Kennedy, 1970). On the formation of the earth, he held similar views to those of Ibn Sina (Avicenna, ca. 980-June 1037). The earth emerged from the natural adjustment of the four elements with each other at the centre of the universe (Ahmad and Baipakov, 2000). As Nasr (1964) points out, Al-Biruni believes in both gradual and slow process at the earth's surface and cataclysms and disasters which from time to time devastate the earth. Al-Biruni proposed that the Indus Valley had once been under sea and that over time, it was filled with alluvial deposits (Kahya and Topdemir, 2002).

On the other hand, the book of Muqaddimah of Ibn Khaldun is basically engaging with the philosophy of history, but it also includes profound statements on geography (Kish, 1978). Al-Khwarizmi wrote a geographical treatise entitled The Face of the Earth, which was essentially a revisited version of Ptolemy's Geography, and it includes maps (Sarton, 1927).

Since pre-Islamic times meteorological phenomena have been of interest to Arabic people due to the practical importance in daily life. The reflection of this practical interest is seen in the works of poets, grammarians and lexicographers (Sersen, 1976; Sayili, 1940). The science of upper phenomena (Ilm al-Atar al-Ulwiye) is related to the meteorological, and this title appears in several books such as Ihsa al-Ulum by Al-Farabi (Alpharabius, ca. 872-950), Mafatih al-Ulum by Al-Khawrizmi and Rasa'il Ikhwan alSafa (Lettinck, 1999). Related to meteorology there are some works that include a number of letters by Al-Kindi (Alkindus; ca. 801-873), the "Chapter on Meteorological Phenomena" from the Kitab as Shifa of Ibn Sina and a commentary on meteorology by Ibn Rushd. Meteorological views of Islamic scholars are mostly adopted from or inspired by Aristotelian theory, but they also criticized it (Lettinck, 1999, 2006). There are two interconnecting understandings of climate in medieval Islamic literature (Straughn, 2006): (1) as topographic descriptions and cartography and (2) climate (atmosphere), which includes weather and seasonality, etc. A number of Muslim scholars wrote about meteorological subjects based on Greek theories such as al-Kindi, Ibn Suwar, Ibn al-Khammmar, Ibn Sina, Ibn Rushd (Averroes, 11261198) and Ibn Bajja (Lettinck, 2006).

Al-Kindi is an encyclopedic scientist and has knowledge of Greek science and philosophy. His works deals with mathematics, astrology, physics, music, medicine, pharmacy and geography (Sarton, 1927). Al-Kindi's contributions include some letters on precipitation and wind. His view in these subjects are different from Aristotle and Theophrastus. He considered the cause of rain to be the motion of the celestial bodies to the north and south that occurs due to the obliquity of the elliptic nature of these bodies, with the sun exerting the most important influence, and he also claims that the clouds are formed when exhalation rises to cold layers of the atmosphere (Lettinck, 1999). Al-Kindi wrote epistles on tides, earthquakes and interior process (Al-Ravi, 2014).

The Brethren of Purity (Ikhwan al-Safa) is a product of a secret association established at Basra about 983. They wrote a series of 52 treatises (Rasa'il Ikhwan al-Safa) of which 17 parts of these treatises deal with natural sciences in which there are explanations of many natural phenomena - tides, earthquakes, eclipses, etc. (Sarton, 1927). They discussed the position of the earth in the universe, elements, minerals, natural process, rocks and stones, stratigraphic sequences, origin of mountains and long geological time (Al-Ravi, 2014; Noyan, 2014). In the Ikhwan al-Safa, precipitation and wind are explained by high mountains and cold causing the consolidation of clouds (Lettinck, 1999).

Ibn Sina has a philosophical encyclopedia named Kitab al-Shifa (Book of Healing), and his most important medical work is Qanun (Canon). In his Kitab al-Shifa, he describes the formation of clouds saying that clouds are densified vapour flouting on air (Lettinck, 1990). Ahmad and Baipakov (2000) explain that

Ibn Sina's observations on earthquakes are interesting. They occur due to the movement of a piece of the earth underneath. The earth is either smoky and vapors, as powerful as wind, or a flowing watery body, or on airy body. Sometimes earthquakes occur due to causes above the earth, such as mountain peaks or large blocks (of stones) falling violently and causing an earthquakes. 
According to Ibn Sina an earthquake is caused by the movement of some parts of the earth, caused by a windy body (al-jism al-rihi) that originates the breath of the earth (like Aristotle) of a fiery body which is the main cause of earthquakes (Baffioni, 2011). Ibn Sina explains earthquakes as a sudden rise of a part of the land or as an erosive action of wind and floods (Needham, 1959a, b). Ibn Rusd accounts in his Short Commentary of the formation of clouds and precipitation the following: the sun dissolves from earth two exhalations, a hot, dry exhalation and a hot, moist exhalation (Lettinck, 1999). Ibn Sina's treatise on "minerals" was main source of the geological ideas of Christian encyclopedists of the 13th century (Sarton, 1927). He divides minerals into four categories: stones, liquids, sulfur and salts (Ahmad and Baipakov, 2000). In the earth science Ibn Sina was interested in the structure of the earth; the mountains that change in the landscape over time due to external factors; and rains, winds and rivers, all of which caused the landscape to be eroded and modified (Kahya and Topdemir, 2002). The observations of earthquakes and nature in general received a new stimulus from the works of Ibn Sina (Guidoboni, 1998). In his Kitab al-Shifa Ibn Sina presents his views on the formation of the earth, seas, mountains, etc. (Ahmad and Baipakov, 2000). He also explains how fossils formed (Montgomery and Kumar, 2015):

The cause of this is a powerful mineralizing and petrifying virtue, which arises in certain stony spots, or emanates suddenly from earth during earthquakes and subsidences, and petrifies whatever comes into contact with it...

Khwarizmi (ca. 780-ca. 850) a Muslim mathematician, astronomer and geographer, attempted to unite and harmonize Greek and Hindu science. His algebra (Hisab al-Jabr welMekabele) is important in the history of mathematics. He in his book Kitab surat al-Ard lists longitudes and latitudes of cities, mountains, sea coasts and islands and detailed courses of rivers (Sesiano, 1997). The most eminent Muslim physicist was Ibn Al-Haytam, and in his chief work of Optics he showed great advance in the experimental method (Dampier, 1961). His great optical treatise, named Kitab al-Manazin (Book of Optics) with important applications to meteorological phenomena was first printed in 1527 as Opticae Thesaurus (McPeak, 1997, 1998).

Al-Farabi (in Latin Alpharabius), a Muslim neo-platonist and encyclopedist, continued the harmonization of Greek philosophy with Islam. This harmonization was begun by AlKindi. And all this was prepared a way for Ibn Sina. Farabi has a number of commentaries on Aristotle (physics, meteorology, logical treatises, etc.). One of the most important books of Farabi is Kitab Uhsa al-Ulum (On the Introduction of Knowledge). This book deals with the classification of sciences.

There are several authors which have books related to the earth sciences. For example, Utarid Ibn Mohammed al-Hasib has the oldest Muslim lapidary (gemologist) extent of research which deals with properties of precious stones (Sarton, 1927). The main work of Abu-1 Hasan Ali Ibn Sahl is Paradise of Wisdom (Firdews al-Hikma) and deals mainly with medicine but also with philosophy, meteorology, zoology and astronomy (Sarton, 1927). Abu Ali Ahmet Ibn Umar Ibn Rusta complied an encyclopedia called The Very Precious Things (Al Alaq Al-Nafisa) that contains an introduction dealing with the celestial and terrestrial spheres and describes countries (Sarton, 1927). The main work of Masudi is named Meadows of Gold and Mines of Precious Stones (Maruj al-Dhababa wa Maadin al-Jawahir). He in this book has a true curiosity (description of the earthquake of 955, waters of the Dead Sea, geological discussions, etc.) (Sarton, 1927). There are a number of similarities with Ibn Sina and Fakr al-din al-Razi. Razi in his Mabahith al-Mashriqiyya introduced (Baffioni, 2011) that

As to the cause that above earth, it is because small (pieces) of mountains fall and then earth is shaken by earthquake.

\section{Ibn Sina explains (Baffioni, 2011) that}

Sometimes there are for earthquakes causes above the earth, like a mountain to which it happens that small or big of its parts fall down violently so that the earth is shaken by an earthquake.

This theory is attributed to a certain "Arakimas" who from context must be "Anaximenes" (Baffioni, 2011).

Aristotle's Meteorologica was translated into Arabic about 820 by the Jewish scholar Yahya ben al Bitriq. These translations was used by Ibn Sina, Ibn Al-Haytam (Al-Hazen) and Ibn Rushd (McPeak, 1998).

The polymath Al-Suyuti (1445-1505) presents a treatise related to earthquakes, and this is the earliest study of earthquakes in the Islamic world. In his Kasf al-Salsala and wasf al-Zalzala earthquakes are explained by the Mount Kaf (or Qaf) metaphor. In this explanation, there is the Mountain Qaf which surrounds the earth and makes places shake by moving the corresponding root (Akasoy, 2006). He also explains earthquakes as a punishment for nonbelievers. When God wishes to punish a people, He orders the angel in charge to animate the appropriate root (Melville, 2002). Al-Suyuti also lists some 130 earthquakes that occurred in the area from Spain to Transoxiana (Melville, 2002).

Related to the earthquakes there are three groups of authors that define and explain it and its effects (Hirshler, 2006): (1) Al-Kindi, Al-Biruni and Ibn Sina explain with pneumatic theories of earthquakes of Aristotle; (2) Al-Suyuti explains earthquakes as God's immediate will; and (3) some authors also explain the cause of earthquakes as astrophysical circumstances such as planetary constellations and comets with long tails.

Also various stones and gems was studied for their medicinal properties (Iqbal, 2007). 
Berberian (2014, p. 84) has mentioned the book titled Kanz al-Masa'il fi Arba Rasa'il (Treasury of Questions in Four Epistles), written by Ibn Sina. In this book of Ibn Sina, Resaleh narrow Miss-e Hoduth-e Zelzeleh va Falsafeyeh (Epistle in the Occurrence of Earthquake and its Philosophy), written by Al-Farabi, earthquakes are explained as the following (Berberian, 2014):

The occurrence of earthquake from 'dry-hot air' ['adkhaneh'] is in this way that since the large amount of 'hot-dry air' which is devoid of water droplets, is light, and is a kind of air, is formed out of its original place. Therefore, it is inclined to escape from an imprisoned location and ascends to reach its natural location. Now if these 'hot-dry air' are located in naturally soft grounds, or areas, which due to large numbers of qanats and deep wells have abundant voids and holes, they can easily escape and would not cause earthquake.

Al-Biruni's views on the earthquake were given as follows (Berberian, 2014):

The calamities which sometimes hit the Earth from up and down have different quantities and qualities. In most cases the Earth has experienced unimaginable severe disasters which were not predictable or treatable. Some disasters such as storms, or earthquakes which are associated with crustal faulting, inundation by water, burring rocks or ashes, thunder and lightning, or rock avalanches, etc., all cause damage and destruction. Hence, a vast area loses its population and after a period of passing the calamity, the area becomes alive again show signs of life.

In the compilation work of Ikhwan al-Safa (971), earthquakes were explained according to Aristotelian views such as (Uysal et al., 2013):

As for the hollows, caves and deep pits in the ground and mountains, when these waters don't have holes to come out, these waters remain in prison for a certain period of time. When the interior of the earth and the depths of these mountains get warmer, these waters also heat up, become thinner and dissolve into steam. It rises and requires a larger space. If the ground shaking occurs a lot, it dissolves, and the vapors come out of these holes. If the density of the earth surface is severe and strong, it prevents the release of vapors. In these pits, they are waved in jail with the desire to come out. Maybe the earth will split through a point and these winds will come out suddenly. Where it comes out also sinks. This is called the sound of collapse and the earthquake. If they cannot find a way out, they will remain in prison. Earthquake continues until the air of these caves and pits cools and the vapors solidify.

Ghazzali (1058-1111) in his The Incoherence of the Philosophers discussed (Marmura, 2000) the possibility of earthquakes as caused by the power of the prophet's soul and related all the activities to Allah (God):

... His soul then looks toward the blowing of a wind, the falling of rain, an attack of a storm, or a quaking of the earth for the annihilating of a people - all this being contingent on the occurrence of coldness, heat, or motion in the atmosphere - causing the cold or heat in his soul, from which these things are generated without the presence of a manifest natural cause. This, then, would be a miracle for the prophet...

In 1020, Ibn Sina considered the cause of earthquakes as steam (locked inside the earth without any escape route except explosion and violence) under the influence of the heavens. He also noticed the topographic changes in the earth, such as the elevation of the ground during severe earthquakes (Nasr, 1964; Al-Ravi, 2002). Ibn Sina states that part of the earthquake caused something which was moving. Then he discusses what kind of object he will evaluate to move in the ground and cause the ground to move. This reason (Lettinck, 1999) can be smoky exhalation like a wind: the wind is strong because it can break a jar if it is pressurized inside. Or it may be running water or air or fire or earth. In its pure form, there is no fire in the earth, but it (fire) can occur in the form of ignited wind or exhalation. A new impulse has been created by earthquake observations and studies of nature by Ibn Sina in general. Volcano and earthquake activity is evidence of the presence of wind trapped in the interior (intestines) of the earth (Guidoboni, 1998). Ibn Sina made wonderful geological observations and comments such as the earth's elevation due to earthquakes in the 11th century (Berberian, 2014; Adams, 1954; Holmyard and Mandeville, 1927):

The formation of heights [mountains] is brought about by [i] an essential cause, and [ii] an accidental cause. The essential cause [is concerned] when, as in many violent earthquakes, the wind, which produces the earthquakes, raises a part of the ground, and a height is suddenly formed [uplift].

The famous poet and mathematician Omar Khayyam's (1048-1131) only Rubai which may be associated with the earthquake (there is also the metaphor of the ox) is as follows (by the English of Fitzgerald; Arnot, 1908):

In heaven is seen the bull we name Parwin,

Beneath the earth another lurks unseen;

And thus, to wisdom's eyes mankind appear

A drove of asses, two great bulls between! 
In 1186, Shahab al-Din Sohrevardi (ca. 1145-1234) discussed various earth phenomena (minerals, spring waters and earthquakes) in the light of observations. According to the Suhreverdi doctrine - Zoroastrian Gnostics used it in almost all their writings - earthquakes are said to be due to underground water vapours stuck in the bottom of the earth; heating water causes steam and heat to light. Therefore, the main reason for all these changes is "light" (Berberian, 2014). This view is explained as follows (Bekiryazıc1, 2015, p. 500):

It is only due to condensed steam that the waters flow towards their natural deposits and from the springs. Earthquakes are also like this. The cause of the vapors has been previously explained. So the real reason for all the movements is light.

Jalāl ad-Dīn Muhammad Rūmī (1207-1273) rejected the thought of earthquakes being caused by entrapped vapours in the earth and said that the idea was believed by the ignorant. He stressed that earthquakes were caused from God's will and decision (İzbulak, 1999):

Qaf (or Kaf) mountain said: Those mountains are my veins... they are not equal to me in beauty. I have a secret vein in every city... The sphere of the world connected to my veins. God tells me if he wants to make earthquakes in a city, I will move the vein up there.

In his Kitāb al-'ajā'ib wa al-gharā'ib Zakariya Qazvini (1203-1283) thought that the effect of the vapours was the breaking of the ground, and this caused damage and destruction. In the German translation of the work (Ethe, 1868, pp. 303-304) it is expressed as follows:

When a large number of water vapor and smoke vapor are combined to form a whole... And the surface of the earth is solid without voids and nonporous, if this is the case, if the vapors want to rise, the pores and passages will not find, as a result, the individual hits of the earth will create shaking (earthquake) and begin to act more violently. Just like the body of patients with severe fever is affected... In these, igniting with the heat that is planted by nature, makes it fluid, dissolves, turns it into steam and smoke and comes through the pores on the skin of the body; as a result, the body vibrates and shakes, until the substance is exhausted. When they go out, relax. Similarly, individual regions have now taken action in the earthquake.

Al-Suyuti (1499) rejected the air theory trapped in the earth's cracks. Influenced by Islamic theology, Al-Suyuti emphasized that earthquakes occurred only with the power of Allah (God).

Averroes states that earthquakes are caused by dry exhalation that moves and returns to the ground (Lettinck, 1999).
He mentions the following confirmatory facts: only the wind (air) between the elements can develop a motive force strong enough to shake the place, just as it can ignite fire and cause waves on water. Earthquakes occur most often when wind is formed, that is, in spring and autumn. When no wind blows, that is, they do not exist in extreme heat and cold. The effective cause of these earthquakes and winds proves to be similar.

\subsection{Pre-modern science in the Ottoman period}

The history of the Ottoman Empire may be divided into two periods, or episodes, known as the pre-modern (or classical) period and the modern period. Science in the Ottoman Empire came into existence in the pre-modern period as a mixture of natural history and natural philosophy. This mixture was based on the scientific traditions and institutions of Seljuk Turks (İhsanoğlu, 2004; Ozcep and Ozcep, 2014). These scientific activities were performed on a large scale by scholars of different Islamic countries such as Egypt, Syria, Iran and Turkistan. The modern period began in the 17 th century when there was exposure to European scientific literature via translations and personal observations by Ottoman ambassadors (İhsanoğlu, 1997).

The foundation for science and education in the classical period of the Ottoman Empire was the madrasas, or colleges. Activity at the madrasa continued from the beginning of the Ottoman state (the first madrasa was established as Iznik Madrasa in 1330) to the turn of the 20th century (İhsanoğlu, 1997). Original works in mathematics, astronomy and medicine were carried out, and the results translated into Arabic, Turkish and Persian (İhsanoğlu, 1997). As Hagen (2012) emphasized, the systems of knowledge and knowledge production were centred on the Ottoman imperial household and the households of the governing elite, together with the upper echelons of the learned class (Illmiye). For Ottomans, the acquisition of knowledge was largely for practical purposes. This was the first communication between Western science and the Ottoman Empire in that region (İhsanoğlu, 1997), and via emigrant Jewish scholars, the Ottomans made contact with Renaissance science (İhsanoğlu, 1997).

Ancient Turks considered (Kahya, 2002a, b) the universe a whole. For this reason, according to Kahya (2002a) they gave importance to human beings, animals, plants and the sky, and the events that occur in it. In the Oghuz Khan epic, one of the most significant epics produced by Turks, natural relationships were presented such as countries, seasons, climate and cosmology. Eberhard defined traditional Turkish religion as a "Turkish sky" religion composed of the cults of the sun and the moon (Gungor, 2012). On the other hand, the scientific background of Turks who settled in Anatolia was Islamic, and they accepted Islamic cosmology that was based on the religion and developed in accordance with the Quran (İhsanoğlu and Ayduz, 2002). 
One of the most important Turkish scholars (of the medieval Islamic world) is Mahmud Kasgari, who compiled the first Turkish dictionary. In his Divan-i Lugati Turk (Dictionary of Turkish Languages) there are definitions for 750 words, and the dictionary also included a world map that is a precious document in the history of geographical studies (Kahya and Topdemir, 2002).

Yusuf Has Hacib (Yusuf Balasaguni, 1018-1077), another important thinker of the era, presented his work titled $\mathrm{Ku}$ tadgu Bilig (Wisdom of Royal Glory), which defines knowledge as flames (Meshale) that illuminate the path of people (Kahya and Topdemir, 2002).

Ottomans encountered numerous scientific traditions, chronologically and spatially. These scientific traditions stem from the Islamic world, Byzantine world, Mediterranean world and Western Europe (Shefer-Mossensohn, 2015). The term ilm was used by the Ottomans to refer to knowledge (or wisdom) and science and the intentional and systemized engagement with knowledge. It contains a rich world of meanings, ideas and insights (Shefer-Mossensohn, 2015). Ottoman scholarship was bounded by traditional Islamic concepts which saw religious learning as the only true science whose sole aim was the understanding of God's word (İnalc1k, 1973). Ibn Khaldun divides human sciences into two categories: (1) the aqli (rational sciences) and (2) naqli (transmitted religious sciences). The Ottomans fully adopted the twofold classification system of sciences made by Ibn Khaldun (İhsanoğlu, 2005). Mevzuat al-Ulum was written in Arabic by Taskopruluzade and translated into Turkish by Kemalettin Mehmed (in Istanbul in 1897). This book describes the traditional Islamic-Ottoman comprehension of science (Cevikel, 2010). As an example, Taskopuluzade in his famous book of Mavzu'at al-Ulum classifies sciences as (İhsanoğlu, 2005):

1. theoretical sciences (theology and natural and mathematical sciences)

2. practical sciences (ethics, politics, administration and domestic economy)

3. sciences prescribed by religious law

4. esoteric sciences or knowledge of the inward (Ilm alBatin).

Detailed classifications of natural science according to Taskoruluzade are the following (Izgi, 1999):

1. Ilmul Tip (medicine)

2. Ilmul Baytara (veterinary science)

3. Ilmul Beyzere (health protection and treatment of animals such as hawks and falcons)

4. Ilmu Nebat (botanical science)

5. Ilmu Hayvan (zoology)
6. Ilmu Felahat (agriculture)

7. Ilmu Meadin (mineralogy)

8. Ilmu Cevahir (gemology)

9. Ilmu Kevn ve'l Fesat (meteorology)

10. Ilmu Kavsi Kuzeh (study of rainbows)

11. Ilmu Firaset (temperament and characteristics of humans based on physical and organic features)

12. Ilmu Tabiri Ruya (interpretation of dreams)

13. Ilmu Akvami Nucum (astrology)

14. Ilmu Sihir (science of magic)

15. Ilmu Tilsim (science of talismans)

16. Ilmu Simya (alchemy)

17. Ilmu Kimiya (chemistry).

As shown in the list, half of the sciences are formed as occult sciences. In this context, natural sciences are one of the magician's materials.

One of the earliest accounts of Ottoman science is Adnan Adivar's La science chez les Turcs ottomans that was published by Librairie Orientale et Américaine G.P. Maisonneuve in 1939.

The first madrasas built in the regions mostly populated by Turks were located in Tokat and in Niksar by Danismentogullari in the 12th century (İhsanoğlu and Ayduz, 2002; İhsanoğlu, 2005). The madrasa system inherited from Seljuk Turks was adopted and enriched by the Ottomans (İhsanoğlu, 2005). By the Ottoman period, Al-Gazzali's thought dominated Sunni Islam and the Ottoman madrasas which followed most broad-minded traditions of Sunni Islam (İnalcık, 1973). The Ottoman ruling class (Yalcinkaya, 2010) was traditionally formed in three sections: (1) Selefiye (men of the sword or the military elite) (2) Ilmiye (men of knowledge) and (3) Kalemiye (men of the pen or the civil bureaucracy). Madrasas in the Ottoman Empire were institutions of higher education, but with the opening of new educational institutions beginnings in 18th century, they started to lose importance (İhsanoğlu and Ayduz, 2002). Aristotle's Physica (that was formed in eight parts) is the main source of books on the natural sciences in Ottoman madrasas (Izgi, 1997), and Tabi'yyat (natural sciences) are divided as medicine, veterinary science, the interpretation of dreams, astrology, the science of magic, the science of talismans, alchemy, chemistry and agriculture. Natural sciences were investigated as simple and complex matters. Simple matters are Feleki (astronomic or astrologic) or Tilsim (talismans). Complex matters are a mixture of needed matters such as alchemy or chemistry (Izgi, 1997) 
In the classical period of the Ottoman Empire, Istanbul Observatory was founded by Takiyyuddin Mehmet, the sultan's chief astronomer, for the purpose of correcting Ulugh Beg's astronomical tables (Zinj), and at time it was the only observatory in the Islamic world (İnalcık, 1973). Takiyyuddin increased the accuracy of his observations by making some new instruments. The observatory was no less advanced then Tycho Brahe's. In fact, there were striking similarities between the instruments used by these two astronomers (İnalcık, 1973).

Ottoman interest for Western science and culture started from the late 16th century with a selective approach in the fields (İhsanoğlu and Ayduz, 2002). The process of Ottoman modernization is a complex phenomenon (Burçak, 2008). As Ozdalga (2005) said, modernization not only brought market principles to the economy and more complex administrative controls as part of state power but also new education intuitions as well as new ideologies. Related to modern science in the Ottoman Empire, according to İhsanoğlu, some translation projects began in the seventh century. Because the Ottomans considered themselves above the Europeans in the spiritual and cultural senses, there is no need to fellow intellectual and scientific activities such as the "Renaissance" and "Scientific Revolution" (İhsanoğlu and Ayduz, 2002). But the military superiority of Europe is an exception. The failures of the Ottoman Empire in the military area in the 18th century was the main motivation for reforms and improvements in these areas introduced by administrators (Erdogan, 2013). As a continuation of these efforts, a military restructuring caused the formation of the first modern school of Tibhane-I Amire, and this school was opened in 1827 to fulfil the need of medical doctors for the military (Erdogan, 2013). In this context for military purposes, modern Ottoman institutions were established, first Hendesehane and later Muhendishane (School of Engineering) for modern military training, based on the French system (École Polytechnique) (İhsanoğlu and Ayduz, 2002). Related to development of modern science in the Ottoman Empire, the term Fen was explained as a branch of Ulum (science) and Maarif (education). He defined Fen as Ilm based on reason, experiment and evidence (Yalcinkaya, 2010). Fen never used to refer to the traditional religious sciences.

One of the first translations within astronomy was parts of the French astronomer Noel Duret's work Novea Montuum Caelatium Ephemerides Richenloinane of 1641 by Tezkereci Kose Ibrahim of Szigetvár. This was followed by translations of some atlases including Janszon Blaeu's Atlas Maior (1685) and Andreas Cellarius's Atlas Coestis (translated 1733). Also, there are the translations of Alexis Claude Clairaut's and Giovanni Domenico Cassini's astronomical tables in 1768 and 1772 . To renovate the military in the late 18th century under Sultan Selim, the first attempts at modern reform were started (Taglia, 2015).

Geography, medicine and astronomy appear to be the fields that brought the Ottomans into relation with the mod- ern Western world on several different levels (İhsanoğlu and Ayduz, 2002). The first modern science and engineering institutions in Ottoman Turkey were Hendesehane (1734), Muhendishane-I Bahri Humayun (1773) and MuhendishaneI Berri Humayun (1795). As a higher-education institution, the idea of Darulfunun (House of Sciences) firstly appeared in 1846 and then opened in 1863 (Ishakoglu, 1995). Darulfunun stands as a civil higher-education institution highly different from the madrasas of the classical Ottoman education system with its structure and curriculum (İhsanoğlu and Akyuz, 2002). In this first Darulfunun, science and technology lectures were given as conferences between 1863 and 1865. Called Darulfununi Osmani, the second Darulfunun started its education on 20 February 1870, and it gave lectures in many areas of science and technology to its students and people. The third enterprise in the Darulfunun was founded in 1873 and was divided into five faculties (medicine, law, science, divinity and letters) like European universities (Ishakoglu, 1995). After the enterprise of founding these three Darulfunun, finally Darulfununu Sahane was opened on 1 September 1900. The Faculty of Sciences of today's İstanbul University goes back to the Ulumu Riyaziye and Tabiye Subesi that was established in Darulfununu Sahane in 1900 (İhsanoğlu and Akyuz, 2002).

Among the Ottoman geographers, Piri Reis has been a most important figure with monumental studies in the field. His book named Kitabi Bahriye was submitted to Suleiman the Magnificent in 1525. This book was prepared by using Eastern and Western sources, and it contained maps and plans of the cities in the Mediterranean and Aegean regions (based on personal experiences) (İhsanoğlu and Ayduz, 2002). Another important geographer is Seydi Ali Reis, an Ottoman captain who wrote a Turkish book named El-Muhit related to the oceans (especially the Indian Ocean) and navigation techniques.

\section{Pre-modern and modern periods of geophysical sciences in the Ottoman Empire}

\subsection{Pre-modern period}

Izgi (1997) gives detailed notes related to geology at Ottoman madrasas. The following statements were taken from his book of Osmanli Medreslerinde Ilim. There are no geology courses in the curriculum of Ottoman madrasas. Darul Hilafeti Aliyye Medrese was established after the II. Mesrutiyet (Second Constitutional Period of the Ottoman Empire). Students of this madrasa obtained their geology knowledge from some sources such as Es-Sifa (Healing) of Ibn Sina and El Isaret al tembihat of Ibn Sina, Hidayetul Hikme of ElEbheri, Himet ul Ayn of Necmeddin el-Katibi, El Makasid of Saadittin et-Taftazani and Sehrul-Makalif of Es-Serif. Geology lectures were given in Darul Hilafeti Aliyye Medresesi as Ilmu Tabakatul Araz with a Maadin (mining or mineralogy) course. In this madrasa, Uzun Korulu Ahmet Efendi was 
appointed as a lecturer of Maadin and Tabakat (geology) in 1913. Furthermore, Ali Vahit Efendi of Istanbul taught Ilmu Tabakat-ul-Arz in this madrasa. Kazanli Halim Sabit in his treatise of Islah-I Munasebetiyle mentioned instructing some courses such as Ilm-I Tabakat-ul-Arz (geology) and Riyazi Ilimler (mathematical sciences) to understand the Quranic verses related to the earth and space. From the middle of 19th century, literature in geology began to form in several ways. In the Ottoman Empire, geology for first time was mentioned by Hoca Ishak Efendi in his Местиаi Uluти Riyaziye, where it was given as knowledge about geology together with knowledge about other subjects such as astronomy, geophysics, mineralogy and meteorology.

The first Ottoman geology book was translated by Mehmet Ali Fethi Efendi of Ruscuklu. This book is originally in French, but then it was translated into Arabic. This Arabic translation was secondly translated into Turkish as Ilm-u Tabakat-ul-Arz in 1852. The book presented geological theory in its first part and applications (petrography, stratigraphy, etc.) in its second part. In the end of book, a small geology dictionary in French, Arabic and Turkish was added (Izgi, 1997; Erguvanl1, 1978). According Şengör (2011), the original book is published by Nérée Boubée under the title Géologie élémentaire à la portée de tout le monde, appliquée à l'agriculture et à l'industrie (Paris, 1833). In his analysis of the book Şengör (2011) points out that (1) all technical terms were borrowed from the source text in Arabic (2) without reflecting the simplicity and elegance of original text and (3) the introduction to modern science in Turkey did not only occur through direct translation from European textbooks but through their popularized version of Arabic translations.

The main sources of the books based on mineralogy in the Ottoman Empire are Al-Biruni's Kitabul Cemahir fil Marifetul Cevahir, Ibn Sina's mineralogical parts of Es-Sifa and Nasiruddin at-Tusi's Tangsuhname-I Ilhani. In these books there are the qualities and values of minerals and gems as well as uses of medicine, magic and talismans. This tradition was based in Iran and India (Izgi, 1997).

In his Miftahu's Sa'ade Taskopruluzade mentioned Ilm-ulMaadin (both mineralogy and mining) as a natural science as follows:

Science of mineralogy and mining (Ilm-ulMaadin): this science is related to the nature and colours, occurrences, extraction and the number of mines (minerals).

In his same book he also mentioned Ilmi Cevahir (gems and gemology) as:

Gemology (Ilmi Cevahir): this science is related to both land and sea's gems. By using this science, it is possible to separate the fake and genuine characters of gems.

On the other hand, in Marifetname of Ibrahim Hakki there is some information on minerals and gems. Properties of these minerals and gems were explained in detail (Izgi, 1997). Vakanivis Ahmet Vasif Efendi in his Zikri Hakikat-I Maadin (subtitle of his book Mehasinul Asar ve Hakaikul Ahbar) gave some information about mines (minerals and gems) (Izgi, 1997).

According to Izgi (1997), the main sources in mining, mineralogy and gemology in Ottoman geography are the following.

1. Name: Kitabul Cemahir Fi Marifetul Cevahir. Author: Al-Biruni. Language: Arabic.

2. Name: Tangsuh-name-I Ilhani. Author: Nasiruddin elTusi. Language: Persian.

3. Name: Cevahirname. Author: Muhammed b. Mansur. Language: Turkish.

4. Name: Yakutatul Mehazin Fi Cevahir il Meadin. Author: Yahya b. Muhammed el-Gaffari. Language: Turkish.

5. Name: Risale-I Maadin. Author: El-Madenul Amire Naziri Hasan. Language: Turkish.

6. Name: Cevher-name. Author: Muhammed b. Garduddin el-Halebi. Language: Turkish.

7. Name: El-Malakat ul Cevheriye. Author: Ilyaszade Hayruddin b. Tacuddin. Language: Arabic.

8. Name: Risale-i Mucevherat. Author: Zenel Abidin Efendi. Language: Turkish.

9. Name: Ahcara Su vermek Hakkinda risale. Author: Catalcavi. Language: Turkish.

10. Name: Tazimud-Durer Fi Ilm Hacer. Author: Seyh Ziya-I Antaki. Language: Turkish.

11. Name: Senai Mucevherat. Author: unknown. Language: Turkish.

12. Name: Cevahirname. Author: unknown. Language: Turkish.

Before Tanzimat (reorganization), geographical information and knowledge in the Ottoman Empire were divided into several periods (Akyol, 1940).

1. Some observations on time determination were performed for religious purposes.

2. Needed information about geography due to the growing of the Ottoman Empire was gathered. There are translations from Arabic and Persian followed by original contributions in the field of marine geography (Piri Reis).

3. For practical needs, technical information was produced. 
4. Western science influenced Ottoman geography via translations (Fuyuzati Miknatissiye, Cihannuma, atlases, etc.).

Relating to the modern period, there are books concerning geology in the Ottoman Empire (Erguvanl1, 1978). There are 24 books from the Ottoman period written with Arabic script in Turkish (Erguvanl1, 1978). These books were written for high-school and university (Darulfunun) students, and 70\% of these books have been translated into Arabic, English, French and German. The other $30 \%$ were Turkish contributors with geological examples of Turkey. The first geology book in the Ottoman Empire was written by Mehmet Ali Fethi, Ilmü Tabakatülarz.

Some of these books are given in the following (Ozcep and Ozcep, 2014).

1. 1852 - Mehmet Ali Fethi: Ilmü Tabakatülarz. Arabic translation. 158 pages and 1 figure. Published by Darül tıbatüatül Amire. Properties of this book: written for university students. It includes two main parts (theory and practice). It first time the term "geology" is used in Turkey.

2. 1875 - Abdullah Bey (translated by Dr. I. Lütfi): Ilmülarz vel Maadin. 584 pages and 129 figures. Published by Mektebi Tibbiyei Sahane Matbası, Istanbul. Properties of this book: lecture notes of Abdullah Bey from the School of Medicine and translated by Dr. Binbası Ibrahim Lütfi. This book was the first lecture book in Turkey.

3. 1889 - Halil Ethem: Ilmi Maadin vel Tabakatülarz. 304 pages, 128 figures and 1 coloured map. Published by Mihran matbas1, Istanbul. Properties of this book: it concerns geology and mineralogy.

4. 1899 - Halil Ethem: Muhtasar Ilmi Tabakatülarz. Translated from Hochsetter-Bisching. 165 pages and 59 figures. Published by Mahmut Bey Matbaası, Istanbul. Properties of this book: the original book was written in German and translated. This book was prepared for high-school students. There is some information about and examples of the geology of Turkey.

5. 1907 - Hüseyin Remzi: Ilmütabakatülarz. 106 pages and 50 figures. Istanbul. Properties of this book: this book was prepared for high-school students. There is some information about Turkey's geology.

6. 1844 - Mehmet Nazım: Kitabi Tabakatül Arz vel Maadin. Published by Mektebi Tibbiyeyi Sahane Matbasi.

7. 1887 - Hüseyin Remzi: Ilmülarz vel Maadin. Translation. 48 pages.
8. 1887 - Ali Fuat (translated by Dr. Yüzbası): Tabakatülarz. 298 pages, 48 figures and 2 tables. Istanbul. (Originally written by Archibald Geike.)

9. 1887 - Le Coq (Lökok Pa sa, translated by Rusçuklu SSevki): Ameli Ilmüarz. 101 pages and 8 figures. Published by Mühendishanei Berri Humayun Matbası, Istanbul.

10. 1889 - Mahmut Esat: Ilmüarz vel Maadin. Izmir.

11. 1889 - Mahmut Esat: Madeniyat ve Tabakatül Arz.

12. 1889 - Ibrahim Lütfi: Ilmi Arz. De Lapperent's Precise de Géologie translated by Ibrahim Lütfi. 496 pages and 122 figures. Published by Mahmut Bey Matbaası, Istanbul.

13. 1896 - Fahri Pasa: Ilmülarz vel Maadin. Translated from French.

14. 1898 - Ali (Dr. Binba şs): Telhüsü Ilmü Maadin.

15. 1898 - Esat Feyzi: Ilmülarz vel Maadin. 272 pages and 170 figures. Published by Mahmut Bey Matbaası.

16. 1906 - Dr. Rifat: Tabakatülarz.

17. 1909 - M. Sadi: Ilmi Arz. 196 pages and 119 figures. Published by Matbai Hayriye, Istanbul.

18. 1911 - Ebül Muhsin Kemal: Yeni Ilmi Arz. 166 pages and 97 figures. Istanbul.

19. 1912 - Mazhar Hüsnü: Ilmi Arz. Istanbul.

20. 1913 - Hüseyin Remzi: Ilmi Arz. 92 pages and 75 figures. Istanbul.

21. 1914 - Hüseyin Remzi: Ilmi Arz. 84 pages and 45 figures. Istanbul.

22. 1922 - Ali Kenan: Madeniyat Dersleri. Istanbul.

23. 1923 - Harun Resit: Yeni Ilmi Tabakatülarz. 270 pages and 185 figures. Istanbul.

There are many books related to earthquakes (the causes of the earthquake occurrence) in the Ottoman Empire. In these types of books, generally classical Aristotelian views on earthquakes were debated. Regarding earthquakes (in Arabic Zelzele, Zilzal and Hareketul Arz; in Turkish deprem and yersarsintisi), some books are the following (Izgi, 1997).

1. ca. 1576 - Nurettin Ebul-Hasan Ali b. Muhammed elCezzar: Tahsinu'l Menazil Min Hevliz-Zelazil. Arabic. Properties of this book: this book was written in Egypt. It was written about an earthquake in Egypt. This book was mentioned by Katip Celebi, but an original copy of this book is lost. 
2. 1726 - Recep el-Kostantini: Risaleyi Zelzele. Turkish. Properties of this book: the author dedicated this book to Sultan I. Ahmet. After the 1719 earthquake of Istanbul the book was written for the public to explain the causes and occurrence of earthquakes. The author explained earthquakes as the movement of an ox. The earth is on the horn of the ox. Due to the horn of ox, an earthquake occurs. The author was influenced the book Kesf El Selsela Vesfiz Zelzela that was written by AlSuyuti. The occurrence of earthquakes was explained by Sheria Ulema (religious scientist) as a punishment. On the other side, Hukema (philosopher and/or physicist) explained earthquakes as being caused by vapour due to the sun which is collected underground. Due to the very hot condition of underground, this vapour wants to rise to earth's surface. But it could not rise to the surface. For this reason, the earth is like a sick man shaking, and some materials emerge from earth's interior. This causes an earthquake.

3. Yasin El Omeri (d. 1811): El-Eserul-Celiye Fi'l Havadis'il Arziye. Arabic. Properties of this book: one copy of this book is in Baghdad.

4. Gokmenzade Haci Celebi: Isaret-Numa. Turkish. Properties of this book: this book was mainly related to the 1855 Bursa earthquake, and it has some information from other earthquakes.

5. Es-Risaletul-Cedide fi Tarihi'z Zelzelei's Sedide. Arabic. Properties of this book: this book is mentioned by Ismail Psa of Baghdad, but its author is unknown. A copy of this book is in the Hagia Sophia library (Istanbul). In the preface of this book, the author said that universe is not a place of constancy (sebat) and pleasure (surur), but it is a place of object lesson (Ibret) and pride (gurur). The author explains earthquakes based on Sheria Ulema, as movement of the earth is on the back of an ox and fish. He also mentioned the Hukema views as a compressed vapour in the earth's interior.

In the last periods of the Ottoman Empire, there were some books about earthquakes that were not associated with the madrasa scholars. These are the following.

1. 1890 - Ahmet Tevfik Kocamaz: Hareketi Arz ve eshabi Zuhuru Hakkinda. 45 pages. Istanbul.

2. 1894 - Halil Edhem: Hareketi Arza Dair Birkac Soz. 23 pages. Istanbul.

3. Sebibzade Muhammed Emin (translated by Vamik Sukru in 1896): Hidayetul Tarik li-Izaletiz-Zelzele ve'l -Harik. Arabic translation.

4. Ali Muzaffer Bey: Zelzele Hakkinda Malumat. Istanbul.

5. 1897 - Abdullah Masher: Hareket-i Arz. 58 pages. Bursa.
All these books were based on the translations of Western sources (Izgi, 1997).

Meteorological forecasting in Anatolian-Turkish folklore is represented by the concept of Cemre (or Imre). In the beginning of the spring, Cemre (or Imre) - the increasing of temperature - appears firstly in the air, secondly in the water and lastly in the earth (or soil). Etymologically Cemre in Arabic is fire ember, spark, rising fire and ember flame. Cemre appears in the beginning of spring. Then it rises up to sky. After that it falls on ice, and it melts ice. And lastly it goes down to the earth. Then warmed earth with vapour rises to the air. These cycles of Cemre are called news for spring. According to the classical scholars, the cycles of Cemre are related to the moon and sun's movements. The falling time of Cemre (Pakalın, 1993) was explained to be 21 February (first Cemre), 28 February (second Cemre) and 6 March (last Cemre). Believing in Cemre - which is very common in Turkish culture and are among Arabs, Persians, Mongols and Greeks - has influenced human life and formed different behaviour patterns (Hamarat, 2012).

Meteorological topics are classified with subjects as vapour, fog, rain, snow, hail, wind, lighting, rainbow, meteors, tides, etc. All of these are known as Risale fi AhdasilCevv or Risale Fil Asaril Ulviye in Islamic literature (Izgi, 1997). Meteorological studies in the Islamic world are mainly Kindi's studies. These are based on Aristotle's $\mathrm{Me}$ teorologica. Ottoman madrasa scholars are mainly interested in the moon's motions, rainbows and tides (Izgi, 1997).

These types of books are below (Izgi, 1997).

1. Husamettin el-Tokadi (d. 1456): Risale fi Kavsi Kuzah Arabic. Properties of this book: this book is related to the occurrence of rainbows. The author at the end of the book says that these types of information (belonging to philosophers and religious persons) should not give a value. Bacouse Kuzah is one of the names of Satan (Kaus in Arabic thought before Islam is a rainbow god). The oldest copy is dated $1479-1480$.

2. Muslihuddin Mustafa b. Yusuf (d. 1487-1488): Mukaddimatu's Marifeti Kavsi Kuzah. Arabic. Properties of this book: the author in this treatise mentioned the diffraction of light and the occurrence and properties of the rainbows. The oldest copy in Turkish libraries is dated 1562 .

3. Ubeys el Kocevi (died end of the century): Risale $f i$ Kavsi Kuzah. Arabic. Properties of this book: the book is dated $1479-1480$.

4. Mirim Celebi (d. 1525): Risale fi Kavsi Kuzah. Arabic. Properties of this book: this book is related to the movements of the moon and rainbows and is one of the most comprehensive books related to the subject. Mirim Celebi in his book discussed such subjects as a seeing event, diffraction and the reflection of light. In the clas- 
sical period, it was a most carefully written and comprehensive work.

\section{Deruni Ali Efendi (d. 1786): Risale fi Kavsi Kuzah. Ara- bic.}

There is one book related to the tides in the Ottoman Empire. Abdulkadir b. Ahmet in his Yetimetul-asr fil Med ve'l Cezr criticized the views about the causes of tides as the movements of the sun. There is a copy of this book dated 1675 .

\subsection{Modern period}

Tanzimat (in English reorganization) covers a series of reforms declared by the Ottoman Empire between 1839 and 1876 under the reigns of Sultan Abdulmejid I and Abdulaziz. These reforms, heavily influenced by European ideas, included a fundamental change of the Ottoman Empire from an old system based on theocratic principles to that of a modern state. In the Tanzimat era, studies of geography and geology are classified in three ways: (1) investigations, (2) compilations and (3) teaching. In this context, there are many studies regarding geology and geography. These studies are presented the following paragraphs from Akyol (1940).

Gautier determined all Anatolian shores, islands, capes, etc. in the Ottoman Empire with excellent instruments (Gautier, 1820, 1822). Several topographic maps were produced in the several parts of the Ottoman Empire by the Germans, English, Russians and French. If we look at the geological works in the Ottoman Empire, there are several foreign researchers who mapped the geologic features. Austrian researchers of interest in the Balkan Peninsula include for example Ami Boue, who investigated the Western Thrace and Eastern Thrace and other parts of the Balkan Peninsula geologically. Ami Boue (1847-1881), an Austrian geologist, was born in Hamburg and received an early education there and in Geneva and Paris. At the Imperial Academy of Science in Vienna, he produced important papers on the geology of the Balkan states (1859-1870) and also published some books such as La Turqui d'Europe. French researcher A. Viguesnel (1868) and Austrian Ferdinand von Hochsteller in 1870 (in Thrace), Th. English in 1904 (on the northern Marmara shores), Austrian Franz Taula in 1904 and Croatian Jovan Cvijic in 1908 were also interested in the Balkan Peninsula from geologic and physical geographic points of view. Auguste Viguesnel (1803-1867) was a French traveller, geographer, meteorologist, ethnographer and geologist. In 1803 he was president of the French Geological Society. He investigated the European part of the Ottoman Empire, (Thrace, Macedonia, Epirus and Albania). His reports also include geologic information. Ferdinand von Hochstetter (1829-1844) was a German-Austrian geologist, naturalist and explorer. In 1852 he graduated as a doctor of philosophy with a thesis on mineralogy from the University of Tübingen. In 1860, he was appointed professor of geology and mineralogy at the Vienna Institute of Technology, where he was rector of the university from 1874 to 1875 . He made respected travels extensively in scientific interest, for example to Switzerland, Italy and European Turkey. Franz Taula (1845-1920) was an Austrian geologist, mineralogist and paleontologist. Beginning in 1863 he studied at the Polytechnic Institute in Vienna (later Technische Hochschule Wien), where he was a pupil and assistant to Ferdinand von Hochstetter. He was a full professor of mineralogy and geology from 1844 to 1917. From the 1870s onward, he performed geologic investigations in the Balkans. Jovan Cvijic (1865-1922) was a Serbian geographer and ethnologist, president of the Serbian Royal Academy of Sciences, and rector of University of Belgrade. He is considered the founder of geography in Serbia. He began his scientific career as geographer and geologist and continued his activities as a human geographer and sociologist.

Geologically Istanbul and neighbouring areas were investigated by several authors such as Andrussov in 1900, Pyotr Alexandrovich Tchihatchev in 1844, E. D. Verneuil in 1836, Xavier Hommaire de Hell in 1848, Rudolf Hoernes in 1909, William John Hamilton in 1837, W. R. Swan in 1868 and Alfred Philippson in 1869 (Ketin, 1983). Pyotr Alexandrovich Tchihatchev (1808-1890) was a Russian naturalist and geologist who was admitted into Russian Academy of Sciences in 1876 as an honorary member. He authored geographic and geologic descriptions of Altai, Xinjiang and Asia Minor between 1853 and 1869. He has a comprehensive study of Asia Minor. He became of attaché of the Russian embassy in Istanbul. He took advantage of this 2-year stay there to study Turkish. He undertook during 1847-1863 a series of expeditions in Asia Minor. He performed extensive scientific research and made collections during these expeditions. Xavier Hommaire de Hell (1812-1848) was a French geographer and traveller who carried out research in Turkey, southern Russia and Persia. Hommaire graduated as an engineer from the École des Mines in Saint-Étienne in 1863. In October 1834 he went to Turkey. He coordinated the construction of a suspension bridge in Constantinople and a lighthouse on the Black Sea coast in 1843. He became a member of the Société de Géographie and Société Géologique. Rudolf Hoernes (1850-1912) was a Austrian geologist born in Vienna. He studied under Eduard Suess and became a professor of geology in Graz. In 1893 he published a detailed textbook on earthquake studies (Erdbebenkunde). He proposed a classification of earthquakes, volcanic earthquakes and tectonic earthquakes in 1878. William John Hamilton (1805-1867) was an English geologist, born in Wishaw, Lanarkshire. He became a fellow of the Geological Society of London in 1831. In 1835 he made a geologic tour in Armenia and Asia Minor. He was president of the Royal Geographical Society for 1848-1849 and the Geological Society between 1854 and 1866 . He was elected a fellow of the Royal Society in 1855. Alfred Philippson (1864-1953) was a German geologist and geographer. He received his education at the University of Leipzig (PhD in 1866). In 1892 he became Privatdozent at Bonn. Having made voyages through 
Italy, Greece and Turkey, he published his studies. He undertook an annual journey to Asia Minor for the purpose of a geologic investigation.

Asia Minor (Anatolia) was investigated by several researchers such as W. J. Hamilton, William Francis Ainsworth in 1842, Ch. Fellows in 1841, William Trowbridge Merrifield Forbes in 1911, Charles Texier between 1839 and 1849, Hommaire de Hell between 1853 and 1860, Tchihatchev in 1867, A. Boue, Gejza von Bokowski in 1903, F. Schafner in 1907, Edmund Neuman in 1893, and Fritz Daniel French in 1916. William Francis Ainsworth (1807-1896) was an English surgeon, traveller, geographer and geologist. In 1836 Ainsworth, after studying under Sir Edward Sabine, was appointed surgeon and geologist to the expedition on the Euphrates River under F. R. Chesey. He went to Mesopotamia through Asia Minor in the passes of the Taurus Mountains. On his return from the Euphrates expeditions, he published his observations. In 1842, he published an account of the Mesopotamia expedition entitled Travels, Researches in Asia Minor, Mesopotamia, Chaldea and Armenia in 1844. Charles Fellow (1799-1860) was a British archeologist. In 1820 he settled in London where he became an active member of the British Association. In 1838 he went to Asia Minor. He published A Journal Written During an Excursion in Asia Minor in 1839. William Trowbridge Merrifield Forbes (18851968) was a professor in the Department of Entomology at Cornel University. He published several papers. Felix Marie Charles Texier (1802-1871) was a French historian, architect and archeologist. Texier published a number of significant works including personnel travels throughout Asia Minor and the Middle East. This book included descriptions and maps of ancient sites and reports of regional geography and geology. In 1840 he became deputy professor of archaeology at the Collège de France. Gejza von Bokowski (1858-1937) was an Austrian geologist, and he received a $\mathrm{PhD}$ from the University of Vienna. From 1855 to 1889 he worked at the Paleotological Institute of the university. Franz Xaver Schaffer (1876-1953) was Austrian geologist and paleontologist. He received a $\mathrm{PhD}$ at Vienna University in 1899. From 1900 to 1936 he worked at the Vienna Natural History Museum. He was a university professor in Vienna. Heinrich Edmund Neuman (1854-1927) was a German geologist regarded as "the father of Japanese geology" in the Meiji period of Japan. He was hired by the Meiji government in 1875 as a foreign adviser, with the task of studying the science of geology of Japan. After his return to Germany he continued his work in geology, making important contributions to the geologic understanding of Anatolia and Mesopotamia. Fritz Daniel French (1861-1917) was a German geologist and paleontologist. He began in 1860 in the natural sciences at the Humboldt University of Berlin. In 1885, he received his doctorate in Berlin. French became president of International Commission for Paleontology. In the First World War, he was appointed a chief geologist in the German army. Some of his studies are concerned with the Alpine region in Ukraine as well as Turkey and their provinces.

Eastern Anatolia was geologically investigated by Herman von Abich between 1878 and 1887; Felix Oswald in 1912; R. Reonardt in 1915; Franz Kossmat in 1910; S. Schafter in 1903; Hugo Grothe between 1906 and 1907; and A. Philippson in 1910, 1911, 1913, 1914 and 1915. Herman von Abich (1806-1886) was a German mineralogist, geologist and explorer. In 1842, he was appointed professor of mineralogy at the University of Dorpat. He undertook trips to Armenia and Caucasus countries between 1850 and 1880. In 1853 he became a member of the St. Petersburg Academy of Sciences, and in 1858 he became a corresponding member of the Prussian Academy of Sciences. He visited Tbilisi and examined the geology of the Caucasus. Felix Oswald (1866-1958) was an English geologist and archeologist. He studied at the University of London. In 1898, he accompanied H. F. B. Lynch as a geologist on his journey through Turkish Armenia. The result was his book A Treatise on the Geology of Armenia. In 1907, he became a fellow of the Geological Society of London. Richard Leonard (1870-1916) was a German geographer and geologist. He studied several subjects such as paleogeography and earthquakes. He moved to Asia Minor. Franz Kossmat (1871-1938) was an Austrian-German geologist, mineralogist and geophysicist. He was a professor of mineralogy and geology at the Technical University of Graz. From 1913 to 1934, he was director of the Saxon Geological Survey and director of the Geology and Paleontology Institute at the University of Leibniz. In 1920, he published the first gravity map of central Europe. Hugo Grothe (1869-1954) was a geographer. His works include the weather forecast for expeditions in the Middle East and Austria-Hungary. Grothe's father worked the construction of Baghdad railway in 1902. From 1896 to 1912 he undertook extensive travels in the Muslim world. He wrote a large expedition work in 1900. He founded the Oriental Society in Munich. Alfred Philippson (1864-1954) was a German geographer. He studied geography, geology, mineralogy and economics in Bonn and Leipzig. In 1886, he received a PhD from the University of Leipzig. In the last decade of 19th century he travelled to northern Greece (1893), Istanbul, the Aegean Islands (1896), Russia and Asia Minor (to 1904). In 1904 he became a full professor of geography at the University of Berlin

\subsection{Modern ideas on geologic and geophysical events: the case of Hoca Ishak Efendi}

Hoca Ishak Efendi (1774-1835) was an Ottoman mathematician and engineer. He was born Arta (now Greece) probably in 1774 to a Jewish family. His father converted to Islam. After his father died, he went to Istanbul where he studied mathematics and foreign languages (learning French, Latin, Greek and Hebrew alongside Turkish, Arabic and Persian). As a part of Sultan Mehmet II's attempts at modern- 
ization in 1816, Hoca was appointed to be an instructor of the Imperial School of Engineering (Muhendishane-i Berri Humayun). His main work Mecmuai Ulumu Riyaziye (Collected Works on Mathematical Sciences) was a four-volume text published between 1831 and 1834. Hoca Ishak Efendi's Mecmuai Ulumu Riyaziye mentions several geological and geophysical topics such as minerals, gems, volcanoes and earthquakes. In the fourth volume of his book he explains these events. For example earthquakes were explained by volcanic or chemical causes, like plutonism in geology. In his book he said that:

After a volcanic eruption occurs, an earthquake grows out of volcanic eruptions. For example Lisbon (Portugal's capital) collapsed due to an earthquake. Another example is the Palermo earthquake that occurred due to volcanic lava in 1726, where many buildings collapsed. Finally earthquakes occur due to the volcanic eruptions in the earth's interior, where sulfur and combustible material pass out from the cracks.

A chemical explanation of earthquakes was a view of the philosopher Immanuel Kant (Kant, 2015).

\subsection{Meteorological studies on Ottoman geography}

There have been several meteorological measurements in several times and places since 1838 (beginning of Tanzimat) in such cities as Istanbul, Izmir, Trabzon, Tekirdağ or Merzifon. These measurements were carried out privately by foreigners of the Ottoman government offices (Akyol, 1940).

These historical measurements and observations were investigated by Akyol (1940). Some results of this investigations are presented here. The oldest meteorological measurements was made in the Saint Benoit school between 1839 and 1847 in Istanbul. This first temperature measurements began in the Saint Benoit monastery in Galata (Istanbul) by the priest Dalmas (Dizer, 1993). Also, there are meteorological measurements that were carried out by P. d. Tchicahatchef in 1847, 1848 and 1854 and by A. Viquesnel (1868). Tchicahatchef's observations appeared in the second volume of his book on Asia Minor, Climatologie et Zoologie (Dizer, 1993). In Tchicahatchef's Asie Minor there is climate information of several cities such as Istanbul, Izmir, Trabzon, Kayseri, Bursa, Sakız, Erzurum, Erivan and Mosul (Dizer, 1993). These observations were made in Haydarpaşa (Istanbul), the Balkan Peninsula, Anatolia (American colleges in Merzifon and Malatya), Syria, Erenköy and Erenköy (Istanbul). There are also personal meteorological measurements that were carried out by Noe, who is naturalist at the Natural History Museum and director of the Mektebi Fununu Tibbiyeyi Sahane. W. Noe measured the meteorological elements twice a day with own instrument, and since 1847 he had been collaborating with Tchicahatchef for his measurements. After the 1848 fire of Istanbul, meteorological in- struments were damaged. Observation results were given to A. Viquesnel. A second personal attempt to measure the meteorological elements was made by French engineer Ritter in Kuruçeşme (Istanbul) and the Bosporus between 1856 and 1860. The results of Ritter's observations are in his book, Le Bospher et Costantinople (Dizer, 1993). Third personal measurements were made by French army major Grellois (those measurements were mentioned by Viquesnel) between 1854 and 1856. There are also the meteorological measurements (temperature and precipitation) that were carried out by foreign companies which worked in railway construction in the Ottoman Empire. These measurements were mentioned by R. Fitzner in 1902 and 1903.

There are some meteorological observations by William Lare. He was a mechanical engineer in British army, and after his sickness he stayed in Istanbul. Then he worked in civil works in the Ottoman Empire. During the last years of his life he continued as a safeguarder of the British cemetery. He was interested in meteorology and made several measurements (Unver, 1973). Meteorological observations were carried out in Thomson Farm in Erenköy (Istanbul) between 1875 and 1892, and these data were published by Retly in 1928 (Unver, 1973). There were some temperature, pressure, and moisture and precipitation measurements in Büyükdere (Istanbul), where a meteorological station was established in a Russian summer house. These data were published in Annales de St. Petersburg (Unver, 1973).

\subsection{Seismological studies on Ottoman geography}

Historical records show that Ottoman geography (especially the Anatolian Peninsula) has experienced many major earthquake shocks that have damaged and destroyed urban centres. For example, the Sea of Marmara earthquake on 10 September 1509 destroyed the city of Istanbul and was one of the largest earthquakes in the previous 5 centuries (Kepekci and Ozcep, 2011).

As Bein (2008) discussed in detail, related to the earthquakes Ottoman intellectuals have some ideas, both theological-cosmological explanations and naturalist theories. For example, Mustafa Ali (d. 1599) rejected the Aristotelian theory and repeated the opinion that God caused earthquakes in response to human sins (Bein, 2008). More significant was the highlighting of God's control over natural phenomena and the direct link between human behaviour and events in nature. For another example in the 17th century, Solakzade Mehmed Celebi (d. 1657) described in a similar manner how an Ottoman sultan told his viziers and military commanders that their sins had caused a severe earthquake in Istanbul in 1509. The tremors and destruction were so severe at the time that the appellation "little apocalypse" (Kryamet$i$ Sugra) was attached to this earthquake (Bein, 2008). On the other side Erzurumi Ismail Hakk1 (d. 1780) has a dualistic approach involving the citation of both theological and Aristotelian explanations. A complete dominance of natural- 
ist explanations based on new European theories of earthquakes was begun by Hoca Ishak Efendi in his Местиa-i Ulum-i Riyaziye. The volcanic theory and the alternative gaspressure explanation were accepted among the Ottoman intelligentsia by the $1860 \mathrm{~s}$. Ahmed Cevdet Pasha reported observations of the 1855 Bursa earthquake and related events such as the appearance of saltpetre steam and fires as an evidence of "the birth of a new volcano" (Bein, 2008).

Main interest in earthquakes among the Ottomans began with the 1894 Istanbul earthquake, the greatest earthquake of 19th century in Ottoman geographies. The earthquake happened at noon on 10 July 1894 . To minimize the earthquake panic in the people, Sultan Abdul Hamid II wanted Aristid Coumbary (director of the observatory) to prepare an earthquake report. Furthermore Dimitrios Eginithis (director of Athens's observatory and an expert in seismology) was invited by Sultan Abdul Hamid II to observe and prepare for the earthquake effects.

The Ottoman government assigned the steamship to Eghenitis to use for his studies. He, Coumbary, Emil Lacoin (deputy director of the observatory) and Vasif Bey (marine officer) began to study the earthquake effects in the field. Eghenitis prepared a report (in French) of this earthquake by using field observations and observations obtained by telegrams, etc. In the report there is also an isoseismal map of this earthquake based on these observations. This report was presented to the Ottoman government on $15 \mathrm{Au}$ gust 1894. In the isoseismal map there are five intensity zones (or contours). In the first zone there are the strongest damaged places from Çatalca to Adapazarı (and along Izmit Bay which includes Esenköy and Maltepe). An isoseismal map is in the form of an ellipse. The second zone includes Carli, Tekirdağ, Mudanya, Akhisar, Üsküdar, Ortaköy and Terkos, and in these sites some buildings (that were not well-constructed) were damaged. The third zone includes Bandirma and Karaköy (near Bilecik), and there is no damage but for the movement of some furniture and belongings. The fourth zone includes Ioannina, Bucharest, Crete, Greece and Konya, and there was no damage, but the earthquake was felt in these sites. The last zone is defined as an instrumental zone where this earthquake was recorded in Birmingham, Pavlovsk and Paris. This report is important for scientists as a main reference and source of this earthquake. Sultan Abdul Hamid appreciated the work of Eghenitis and gave him the "Order of Madjidie" (Fettahoglu, 2002).

As an example in the 17th century, there is an anecdote relating to the 1509 earthquake. The sultan gathered his viziers and commanders. He stated that he told the viziers and military commanders of the Ottoman sultan how his sins caused a violent earthquake in Istanbul in 1509. According to Solakzade Mehmed Çelebi's History (Kınaylı, 1958):

The Sultan, Beyazit II, gathered in the Edirne Palace and made the following address to the viziers with anger:
He said: "These earthquakes are divine, and these are the wrath of God, caused from your cruelty and mischief to the oppressed people."

The famous Turkish poet Tevfik Fikret wrote the poem "Earthquake" after the 1894 earthquake. In his poem, Tevfik Fikret explains that the earthquake is a natural process. He uses the illness metaphor:

The earth, like the nervous and feverish patients,

Suddenly

secretly and long

With a movement It struggled, broke, destroyed... Sadness

The earthquake explanation with Mount Kaf and the ox and fish metaphors conceptualized in Al-Suyuti and Zekeriya al-Kazvinî are also in Ottoman-Islamic mythology in a slightly different way. This is explained as follows (And, 2018):

... What does the world stand on? It is like a ship on the water. God sent a great angel that has infinite power. This angel took the world on her shoulders, stretched one hand to the east and the other to the west... God commands the rock to come under the angel's feet. God ordered Taurus to go under the rock. The bull carried the rock on its back and on its horns. However, a base on which the bull will also set its feet was needed. God created a very big whale (Hût) and was placed under the bull... In the folkloric belief, every hair of this ox is tied to a country, when a mosquito approaches its nose, an ox will shake, whichever hair moves, an earthquake happened in that area...

In his Risale-i Zelzele (Essay on Earthquake) that was written in 1726, Recep el-Kostantini explained earthquakes as the following (Akin, 2012):

...During the great earthquake, when I saw the disagreement of the people at that time, some of them said that the ground motion is caused by moving/awakening the hair of the ox, which is the loading of the ground, and in some others believing/saying that it is the movement (drive) of the fish under that ox, some others would have made it difficult and the surface of the whole place had to be moved if both the ox and the fish movement were like this. We said that it is crazy not to be from ox and fish in some places and not in some places, but Allah (God) knows the true information.

In Maarifetname written by Ibrahim Hakk1, earthquakes are explained by two ways (religious and Aristotelian views) as (Irmak, 1973): 
There have been lands and mountains. Even mountains have been the poles (used as a beam) of the ground. Then Hak Taâlâ (God) tied the vein of all mountains to Kaf mountain, which surrounded the ground. He held a great angel responsible for the earthquake and gave the veins of the mountains to his hands. In this case, when Hak Taâlâ tried to deny and ban the people of a place from rebellion; that angel moves the vein of that place at the command of the God.

O Dear, you know, the philosophers said: This is the reason why the earth is shaken, when the vapor formed in the earth is trapped there; turning to one side, it cools there and turns into water. If it is less, it mixes with the steam pieces. This is well waters. If it is too much, it does not fit into the earth, creating fine places of the earth's crust, it turns out, these are the boiling resources.

As another example, earthquake explanations are given in Resul Mesti Efendi's Siper-i Zelzele (Arslantaş, 2007):

... So, an earthquake occurs when the material that is capable of igniting/firing, which is settled in the ground from the changes of the ground, actually goes out of the ground with the tendency of the steam coming out of the ground to rise up.

\subsection{Soil mechanics: Karl Terzaghi in the Ottoman Empire}

Karl Terzaghi (1883-1963) studied mechanical engineering and received a $\mathrm{PhD}$ at the Technical University of Graz. In 1916 Terzaghi was requested by the Austrian Department of Foreign Affairs to accept a teaching position at the Imperial School of Engineers (now Istanbul Technical University). He accepted this position. After his arrival In Istanbul he learned that the request has been made by the suggestion of Prof. Philipp Forchheimer, an eminent Austrian hydraulic engineer who was at that time engaged in an organization of engineering education in the Ottoman Empire (Casagrande, 1960). When World War I was ended, he took a post (19181925) with Robert College, an American school in Istanbul (now Boğaziçi University). In 1925 he went to the US as a member of faculty at MIT and then Harvard University. He is accepted as the founder of soil mechanics. During the Ottoman period, he was engaged in the study of physical properties of soils. Since 1916 Terzaghi, on the one hand, gave the lectures on "Foundation, Construction, Road and Railway Construction" and, on the other hand, he performed some scientific experiments related to soil mechanics at the Imperial School of Engineering in Istanbul (Ozudogru, 2010). He published an important paper in Engineering News-Records (see Fig. 1) related to the results in studies in this school.

Karl Terzaghi sent two letters to Prof. Hamdi Peynircioglu (a prominent geotechnical engineer in Turkey) in 1946 and

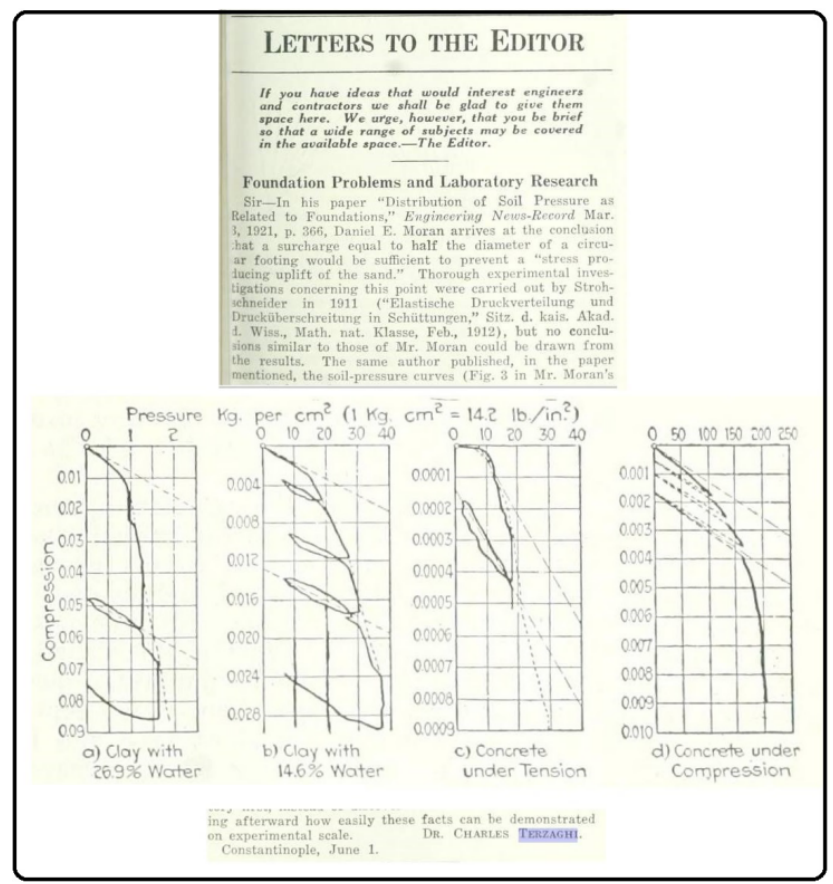

Figure 1. Karl Terzaghi's paper in the Engineering News-Record journal (Terzaghi, 1921).

1950. In his first letter dated 25 April 1946, he sent a photo (that was taken in the Department of Civil Engineering at Robert College) relating to laboratory testing. He says (Bahadir, 1998):

This photo shows the instrument that I use it to test earth pressure. Instrument consists of empty cigar boxes, simple extensometer (that I borrowed from Physics Department) and kitchen balance (that I gave back to kitchen balance after testing). Our test results were published in "Engineering Records" Journal in 1922. But I paid attention to quality of instrument that I used. After 12 years I repeated these tests by special instruments (its price is 60000 dolars) during the construction project that designed in a dam, in Connecticut River, New Hampshire. Results are in agreement with previous tests that I carried out with cigar boxes. This situation should be encouraged some people who carried out the simple instruments.

Information in this letter was confirmed by Casagrande (1960):

Soon after his arrival in Istanbul he built his first earth pressure apparatus. Some of measuring devices he borrowed from the Department of Physics and others from the University kitchens. During this period, he began to lay out a broad program for a systematic investigation of physical properties of cohesive soils... 
... In order to perform his experiments on clay he needed an assortment of soils of this category. Hogly plastic clays could be found only close to the coast of the Black Sea which was separated from suburbs of Istanbul by a broad belt of forest. During the following years all his experiments on clays were performed of these samples. In his book "Erdbaumechanik" they are referred to as clays II and IV.

In the second letter of Terzaghi, dated 6 March 1950, he said:

I consider Istanbul as an always birthplace of my contributions in soil mechanics.

\subsection{Oceanographic studies in the Ottoman Empire}

Oceanographic studies in the Ottoman Empire were started by Luigi Ferdinando Marsigli in the Bosporus (Istanbul) in 1681. He was born in Bologna and supplemented his reading by studying mathematics, anatomy and natural history. After a course of scientific studies in his native city, he voyaged throughout Asia Minor collecting data on the Ottoman Empire's military organization, as well as on its natural history. The first Turkish oceanographer was Ahmet Rasim, who carried out an expedition in the Bosporus and the Marmara Sea between 1894 and 1896.

\subsection{Institutional contributions}

\subsubsection{Rasathane-i Amire (Imperial Meteorological Observatory)}

In 1858 French government established a meteorological network that transferred their data by telegram. Same system was founded in the UK in 1860 . After the testing period, the first French national meteorological network began to work in 1863 (Dizer, 1993). Fettahoglu (2002) investigated in detail the historical development of Rasathanei Amire in the Ottoman Empire. The following information was taken in her study. In 1863 the Ottoman government wanted newspapers to publish weather reports. Daily newspapers published the weather reports after this circular every day. These is evidence of meteorological issues in the country's agenda before the observatory's founding. A proposal for the founding of an observatory was made by Aristid Coumbary (Kumbari Efendi) in a report titled Memoire Sur la Nécessité D'Éstablissement D'un Observatoire Météorologique in 1867. The report is 24 pages, and it includes the necessity of a meteorological observatory and the historical development of meteorology in Europe. Also, the importance of meteorology for maritime (military) and agricultural use is mentioned in this report to establish an observatory. There are two reasons for the establishment of the observatory: (1) the national need of meteorology for military and agriculture and (2) international encouragement for the Ottoman Empire for participating in an international meteorological network.

Finally, in 1868 an observatory for meteorological purposes was established in Istanbul named Rasathane-i Amire (Imperial Meteorological Observatory) by the same data transfer method of telegram (Fig. 2). With the recommendation of Urbain Le Verrier, director of the Paris Observatory (Fettahoglu, 2002), Coumbary Efendi (Aristid Coumbary) was appointed the first director of the observatory. Aristid Coumbary (see Fig. 3), a man of Greek origin born in Istanbul in 1827 or 1828, was son of Yanker Kiryako. He received the first education in a Greek school in Istanbul, and then he continued his education at the University of Athens, and lastly, he completed a diploma at the School of Mathematical Sciences in Paris. He spoke Turkish, Greece, French and Italian (Fettahoglu, 2002). The observatory is located in the Pera region of Istanbul. This location also has the central station, and there are many stations that collaborated with the central station such as Savlina, Constanta, Varna, Burgas, Trabzon, Rhodes, Çanakkale, Kavala, Thessaloniki, Manaster, Jalona, Elbasan, Durrës and Beirut. Later some stations were added to these stations such as Izmir, Diyarbakır and Baghdad (Dizer, 1993). But the first meteorological observations in this observatory are not reliable and were published in their own publications and in European meteorological journals. The most important activity of the observatory is a representation of the Ottoman government at the Vienna International Meteorological Congress in 1873. This congress was on 1-6 July 1873, and there were many contributions not only from Europe but also from the United States, China and Japan (Fettahoglu, 2002). Coumbary Efendi attended to the meteorological congress. He - with delegates of other countries - discussed the physical and instrumental conditions of this observatory at this congress. Through this observatory the Ottoman Empire took part in the International Meteorological Congress in Vienna with an emerging worldwide meteorological network (Benois, 2009). After the congress, Coumbary prepared a report to the Ottoman government related to the congress (Fettahoglu, 2002). In 1887 (24 September) the Ottoman government was invited to the meteorological congress, but due to the financial restrictions it was not able to attend this congress. At the end of this congress, one copy of the final report was sent to the Ottoman government (Fettahoglu, 2002).

There were approximately 10 meteorological stations affiliated with this observatory which reported their daily observations via cable to the Observatory. The central office in Istanbul sent these observations, via cable, to international observatories (in Berlin, Vienna, Paris, St. Petersburg and Hamburg) and received their reports by the same way (Topdemir, 2007; Dizer, 1993). In 1876 the observatory shared it weather information with the British navy.

There are some papers related to the first observatory studies in French meteorological journals such as Annuaire De La Société Météorologique de France, vol. XII, in 1868. 


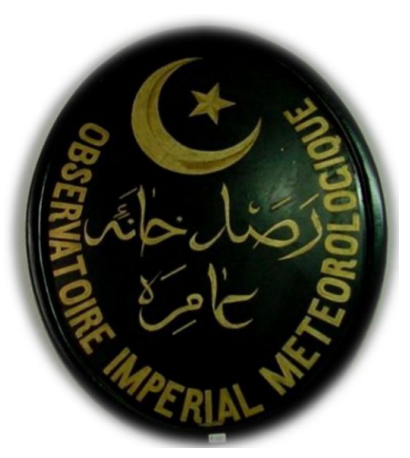

Figure 2. Emblem of the Rasathane-i Amire (Imperial Meteorological Observatory).

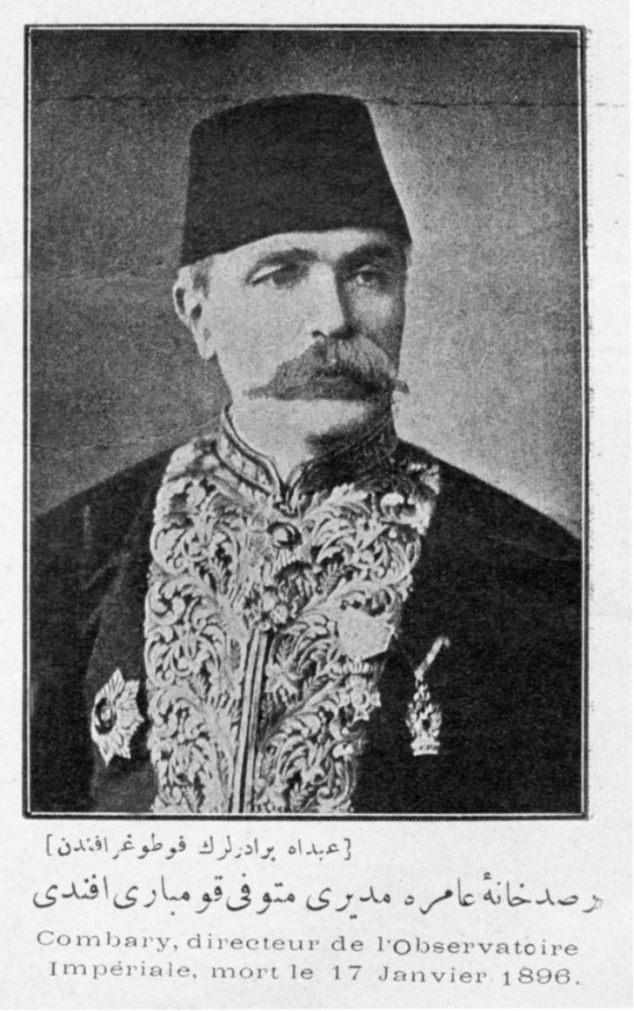

Figure 3. Aristid Coumbary.

Marie-Davie (general secretary of the French Meteorological Society) presented a report in a meeting on 22 November 1968. This report includes results of trips in Hungary, Turkey, Greece and Italy. Also there is a news in Nouvelles Météorologique (issue 9-10) related to the Turkish Imperial Meteorological Observatory in 1868 (Dizer, 1993). In this report the following sentences appear:

Asian and European Turkey are located in the pathway of storms that we are interested in observations that are most valuable. These observations, dark points with highlights, and data will be connected by Russia and India.

Another important issue related to the international relationships of the observatory is that General Albert Maber (USA) sent a letter to the observatory. In his letter General Maber said that every kind of corporation could be possible between the Ottoman government and USA in the field of meteorology. In the same international context, Russia and the Ottoman government have a good relationship in the exchange of data, books, reports and pictures (Fettahoglu, 2002).

Results of meteorologic observations were published with the title Observations Météorologique and by the $1868 \mathrm{Bul}$ letin météorologique de l'Observatoire impérial de Constantinople. In these bulletins there are all observations that were carried out in all stations (Istanbul, Izmir, Beirut, Diyarbakır, Fao, Ruse, Sulina, Varna, Trabzon and Thessaloniki). Also there are the observatory registries that include relations between health and weather events. As an example in an observatory registry (Gozlem Defteri) there are some notes relating to cholera and the ozone amount in the atmosphere (Dizer, 1993).

In 1888 with efforts of observatory staff, Rasathane-i Amire had the following instruments (Fettahoglu, 2002):

- Fortin barometer (big)

- Fortin barometer (small)

- hypso-barometer with recorder

- Richard barometer with recorder

- Robinson Mulin (river measurement)

- pluviometer

- Walferdin thermometer (big)

- Rutherford thermometer (small)

- Ogust hygrometer

- Richard hygrometer

- various thermometers.

These instruments were bought from the Baudin factory in Paris, France. The instruments in the Rasathane-i Amire are shown in Fig. 4.

Between 1868 and 1922 there are three publications of the observatory related to the meteorology. The first is Firtinalarin Kavanini (Lois des Tempêtes avec Dessins et Cartes des Tempêtes) in 1875. This publication was in total 23 pages (11 pages in Turkish) and written by Coumbary in Istanbul. It also includes two maps and one figure. A second publication was titled Dersaadet Rasathane-I Amiresi'nin Cevv-i Havaya Dair Yirmi Senelik Terassudati Neticesi (Meteorological Observation Results of 20 years of the Observatory 
Table 1. Monthly and annual temperature values between 1868 and 1887 (Fettahoglu, 2002).

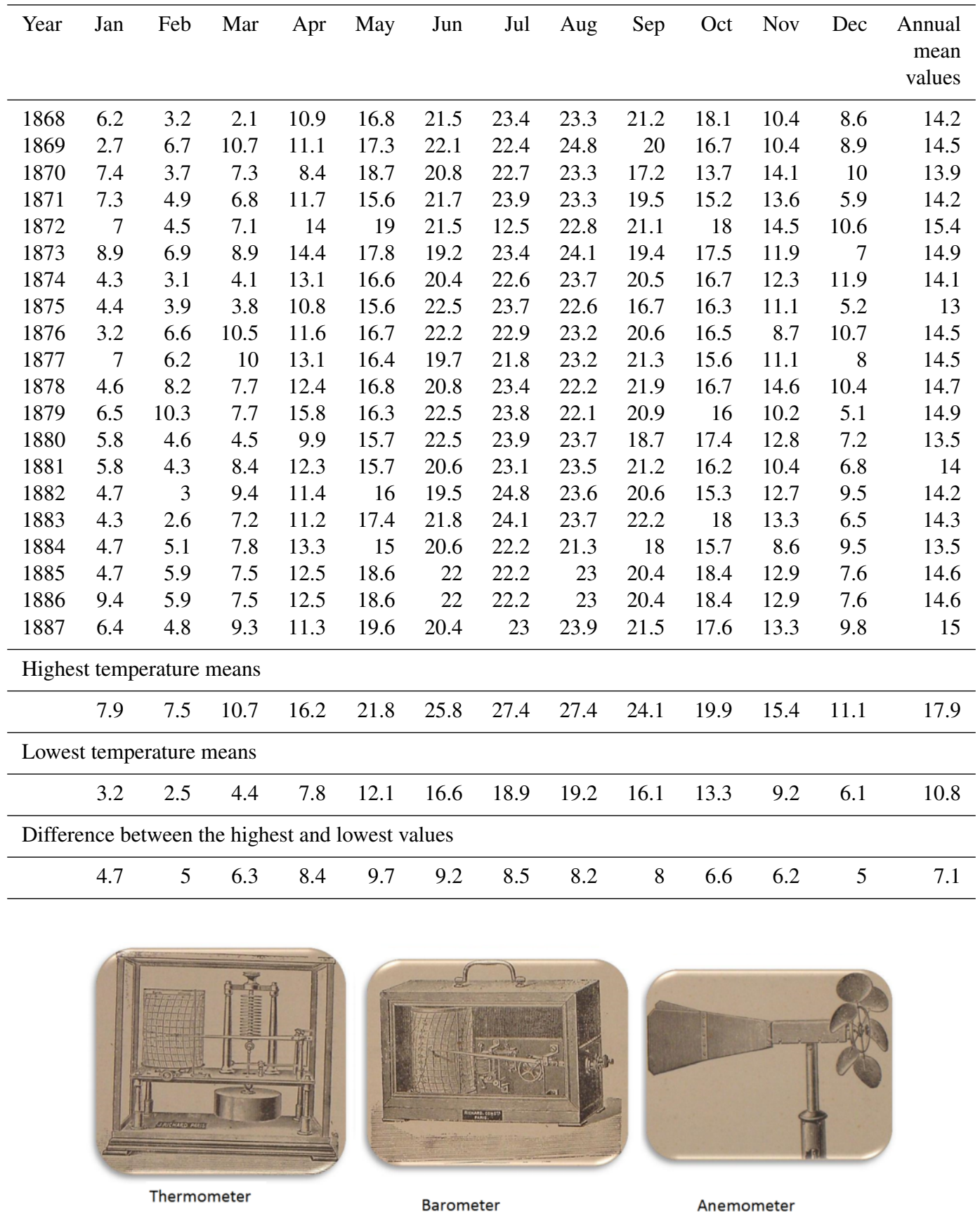

Figure 4. The instruments in the Rasathane-i Amire.

between 1868 and 1887). It was written in Turkish (16 pages) and printed in Matbaa-i Osmaniye. In the introduction of this book, there are pictures of meteorological instruments in the observatory. The book mentioned national units and international organizations that were related to the observatory. The publication includes the temperature, pressure and precipitation data between 1868 and 1887. As an example of data, temperature values at these periods are given in Table 1.
A third publication is named Rasathane-i Amire'nin 1912, 1913, 1914 Senelerine ait Hulasa-I Rasadati (Observation Summary Related to the Years of 1912, 1913 and 1914 in the Observatory). It was written in Turkish in 1915 and printed in Matba-I Amire (in Istanbul) as a 31-page document.

Figure 5 shows storm movement in 1865 in Europe. Figure 6 shows a meteorological report (dated 13 April 1893) 


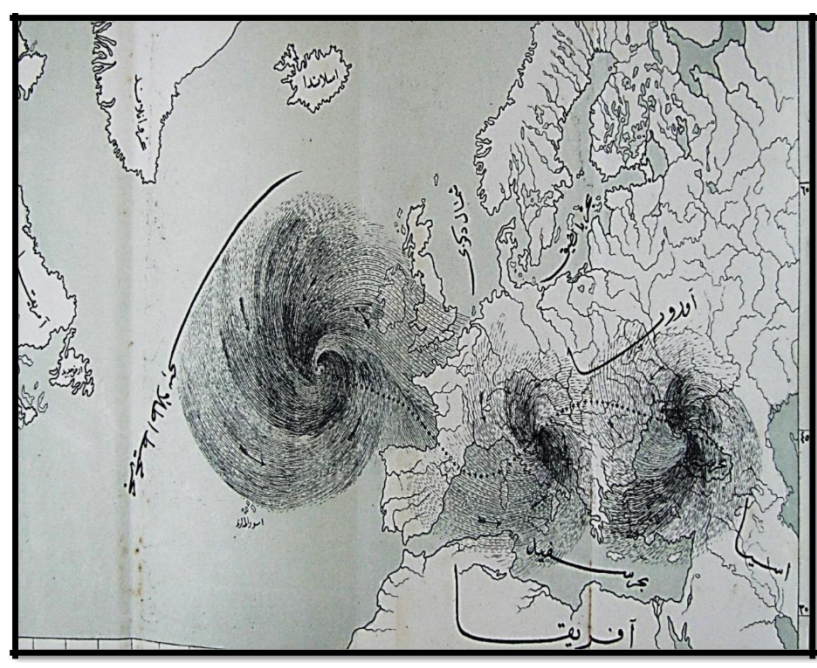

Figure 5. Storm movement in 1865 in Europe.

sent to Yildiz Palace (a residence of the sultan and his court in the late 19th century).

The observatory has an international relationship with many European observatories (mainly the Paris Observatory, Rome Observatory, Vienna Observatory, then Berlin Observatory, Pulkovo Observatory and other observatories in countries such as Italy and Norway). This observatory is important for European scientists as well as the Ottoman government. For example director of Paris Observatory Verrier sent to letters to Coumbary on 5 and 26 May 1869 (Fettahoglu, 2002). In his letters he wrote that the storms on the American shores could be observed in Eastern Europe and that the observatory in Istanbul could meteorologically help in the monitoring of this type of storm. Furthermore Verrier wants from Coumbary the obtained knowledge about weather conditions of the Ottoman geography for a weather atlas (1868). After the following months, Verrier sent a letter of thanks to Coumbary, and he said that science can only develop with international cooperation. This letter was published in a daily newspaper of time.

By the establishment of the observatory in 1868, although there is no seismological research, there was an effort to register the earthquakes that happened and were felt in Ottoman geographies. In this context since 1874 some earthquakes were informed by the observatory according to the newspaper records of date (for examples see Table 2). Furthermore there is some information related to the earthquakes in bulletins of the observatory, such as Observations Météorologique and Bulletin météorologique de l'Observatoire impérial de Constantinople (Fettahoglu, 2002).

The 1894 earthquake had not only a great impact on the people, but also it also became understood that there is no official institution related to earthquakes in the Ottoman Empire. Government-obtained information about possible or fu-

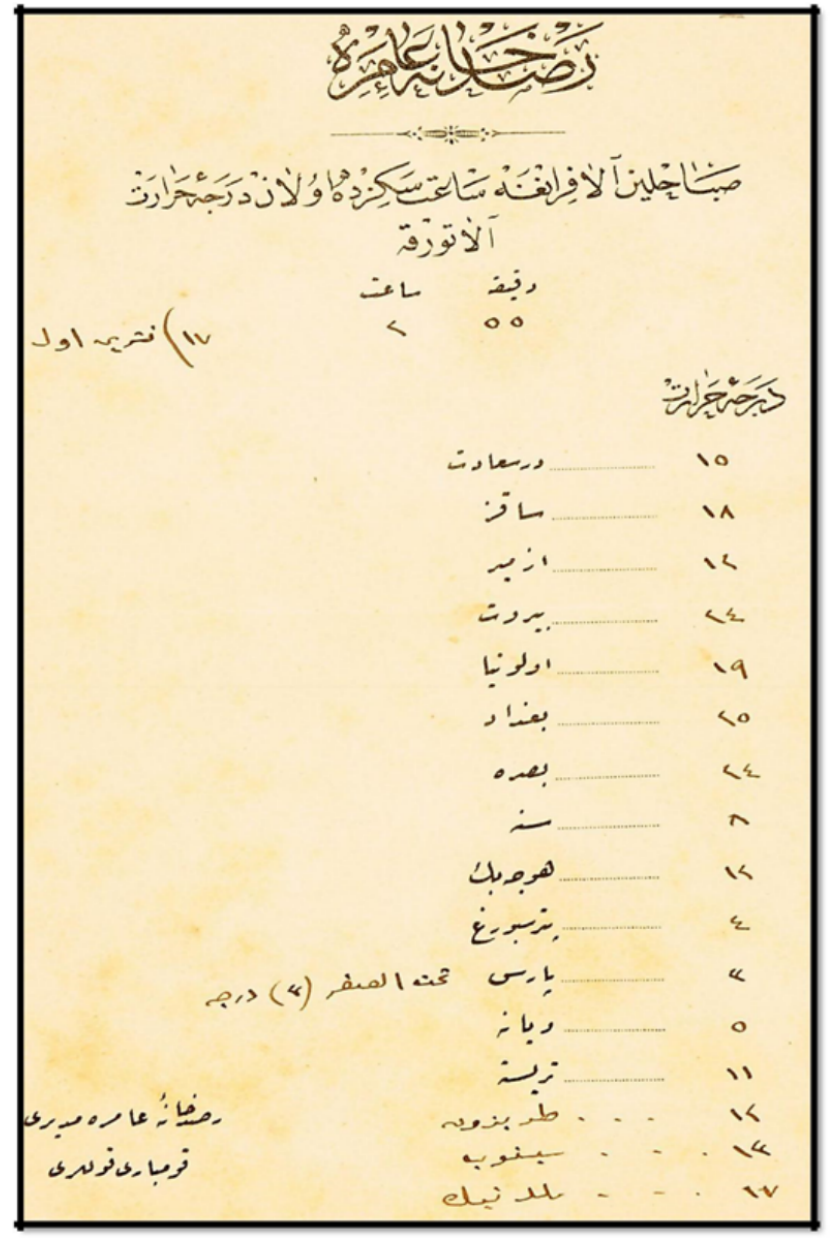

Figure 6. A meteorological report (dated 13 April 1893) sent to Yildiz Palace (a residence of the sultan and his court in the late 19th century).

ture earthquakes was needed to take preventive measures. For this reason some information about buying seismograms was obtained. Regarding buying and then operating seismograms, the government sent written notices to some European embassies of the Ottoman Empire (in London, Paris, Berlin and Vienna). In the replying notices from the embassies, there are several proposals for buying seismograms (see Fig. 7). Then an agreement was accepted that the best seismographs were produced in Italy.

In Rome, the director of the Collegia Romana observatory, Tacchini, said that this type of seismograph could be produced by itself. Another proposal was taken by J. Ewing. He also sent a user manual (dated 1899) of seismographs that were produced by the Cambridge Scientific Instrument Company. The Ottoman government decided to buy the Palmieri seismographs that were developed by an Italian group of Bertelli, Galile Gecci, De Rossi and Giovanni Agamennone. After buying the seismograph, the second problem was the person that operated this instrument. Tacchini's proposal for 
Table 2. Some earthquake information (between 1870 and 1895) to be sent to the Rasathane-i Amire (Fettahoglu, 2002).

\begin{tabular}{|c|c|c|c|c|}
\hline & Location & Time & Intensity & Sources \\
\hline 1 & Vlorë & Morning & Strong & Levant Herald, no. 49, 5 January 1870, p. 381. \\
\hline 2 & İlbasan & & $\begin{array}{l}\text { Strong } \\
\text { (three times) }\end{array}$ & Ruznâme-i Ceride-i Havâdis, no. 1588, 12 February 1871, p. 7188. \\
\hline 3 & İlbasan & & Light & Ruznâme-i Ceride-i Havâdis, no. 1604, 9 March 1871, p. 2. \\
\hline 5 & Kavala & & Strong & Ruznâme-i Ceride-i Havâdis, no. 1611, 19 March 1871, p. 1. \\
\hline 6 & Thessaloniki & Evening & Strong & Ruznâme-i Ceride-i Havâdis, no. 1640, 19 April 1871, p. 2. \\
\hline 7 & Tulcea, Italy & & Light & Levant Herald, no. 2, 31 January 1872, p. 5. \\
\hline 8 & $\begin{array}{l}\text { Diyarbakır, } \\
\text { Chile and Peru }\end{array}$ & & Light & Levant Herald, no. 12, 10 April 1872, p. 85. \\
\hline 9 & Durrës & & & Basiret, no. 861, 26 February 1873, p. 1. \\
\hline 10 & Kavala & Morning & & Basiret, no. 861, 26 February 1873, p. 1. \\
\hline 11 & Yozgat & Morning & & Basiret, no. 861, 26 February 1873, p. 1. \\
\hline 12 & Sèvres & & Strong & Basiret, no. 861, 26 February 1873, p. 1. \\
\hline 13 & Sakız & & Strong & Tercüman-ı Hakikat, no. 1506, 16 June 1883, p. 1. \\
\hline 14 & Sakız & Morning & Light & Tercüman-ı Hakikat, no. 1594, 26 September 1883, p. 1. \\
\hline 18 & Izmir & Night & Strong & Takvim-i Vekâyi, no. 131, 17 November 1891, p. 2. \\
\hline 19 & Urla & Night & Strong & Takvim-i Vekâyi, no. 131, 17 November 1891, p. 2. \\
\hline 20 & Sakız & Night & Strong & Takvim-i Vekâyi, no. 131, 17 November 1891, p. 2. \\
\hline 21 & Sakız & Morning & & Takvim-i Vekâyi, no. 256, 11 April 1892, p. 1. \\
\hline 22 & Corfu & & & MF.MKT, 282/11, 14 September 1895. \\
\hline 23 & Zakynthos & & Strong & MF.MKT, 293/35, 17 November 1895. \\
\hline
\end{tabular}

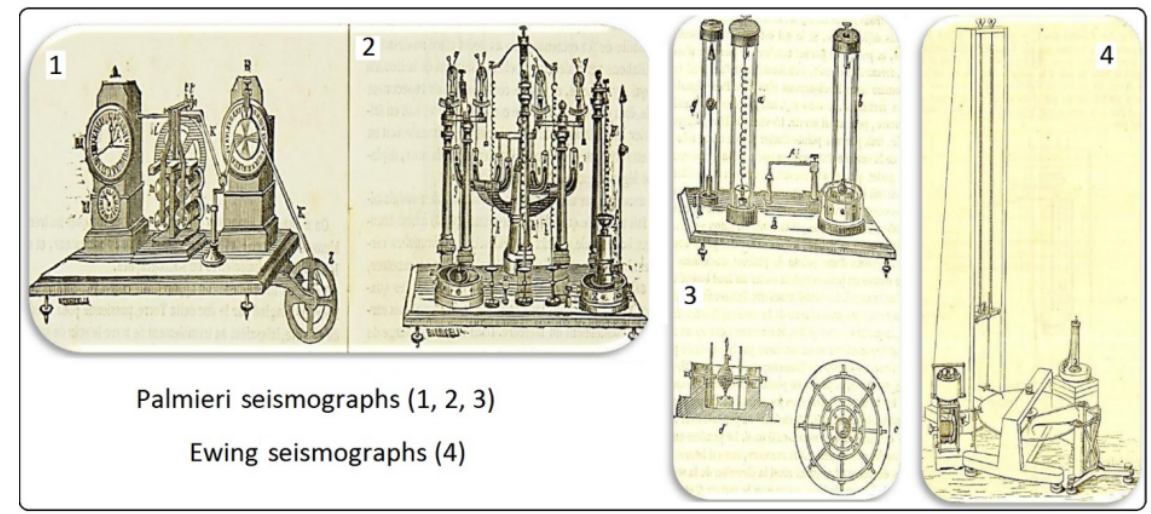

Figure 7. Seismograph proposals for the Ottoman Empire.

expert personnel was Giovanni Agamennone, director of the Geodynamic Division of the observatory in Italy.

Giovanni Agamennone was invited by the Ottoman government to Istanbul to establish the Earthquake Department of the observatory and teach about earthquakes and how to use the seismograph. He had a degree in physics from the University of Rome in 1884. Afterwards he worked as an assistant of geodynamics at the Observatory of Ischia and then the Central Office of Meteorology and Geophysics in 1895. Agamennone registered all earthquakes that happened 
in Ottoman geographies. For this aim, he sent an official notice to all centres of the post office and telegram and railway companies stating that he wants them to inform him about earthquake knowledge in their regions. After the 7 months of construction of the Earthquake Department building, the instruments were moved to this building with Salih Zeki Bey's (director of the observatory at this time) efforts, the Earthquake Department was officially founded in the observatory (Rasathane-i Amire). From 1870 to 1903 earthquake observations were sent to the observatory via post and telegram offices of the government after a government notice. After the founding of the Earthquake Department, these activities became more efficient than in the previous periods. This earthquake information focused on the Aegean Region and Balkan Peninsula. Furthermore there is some earthquake information in regions such as the Eastern Anatolia Region, Black Sea Region, Central Anatolia Region, Mediterranean, Middle East and Marmara Region on the telegrams. Seismographs that were installed in Maçka (Istanbul) recorded some minor earthquakes in Istanbul and the adjoining area. For example, an earthquake (that occurred in Bursa on 26 October 1896) was recorded by these seismographs, and the public was informed via newspapers. In August 1896, Agamennone as a head of the Earthquake Department published a treatise related to the earthquakes that occurred in the Ottoman Empire and its vicinities. This study is a statistical study of earthquakes that happened in Greece, Bulgaria, Serbia, Austria-Hungary, Egypt, Iran and the Caucasus. Furthermore, an earthquake list table was published by the department. Agamennone left the observatory due to economic reasons, and then Salih Zeki was selected to be responsible for the Earthquake Department. Within this period, two important earthquakes happened in Balıkesir (29 January 1898) and in Aydin (1899). To investigate these earthquakes, the observatory administration wanted the fund from the government for field studies (Gunergun, 2005). But the fund did not provide for the first earthquake. For the second earthquake (Aydin) the fund was supplied from the government, and the earthquake group (Salih Zeki and Said Bey) went to Aydın to research the earthquake. But the results of this study are unknown. This research is the only original research attempt of the Earthquake Department. During these years, Agamennone published many papers in Italian and French in scientific journals from 1896 to 1899 (Ozcep and Ozcep, 2014).

Related to the establishment of the Earthquake Department, Charles Davison (prominent seismologist in this era) published a paper in Nature and praised the establishment and Agamennone (see Fig. 8). He said (Davison, 1895):

... with the foundation of a seismological observatory, Dr. Agamennone has also undertaken the organisation of earthquake studies throughout the Ottoman Empire, and he is anxious to extend this very important branch of his work so as to include

\section{The Study of Earthquakes in the South-East of Europe.}

IN two recent notes in NATURE (vol. li. pp. I8o, 468) attention has been drawn to the foundation by the Ottoman Government of a gendynamic section of the Imperial Meteorological Observatory at Constantinople. The new department has been placed under the direction of Dr. G. Agamennone, who for several years held a similar office at Rome, and who is well known to seismologists for the valuable work performed by him in Italy.

Not content with the foundation of a seismological observatory, Dr. Againennone has also undertaken the organisation of earthquake studies throughout the Ottoman Empire, and he is anxious to extend this very important branch of his work so as to include the entire district within and bordering the eastern end of the Mediterranean. As there must be many readers of NATURE who are able, either directly or indirectly, to aid him in this attempt, I should be grateful if you would allow me to recommend it to their attention and support. Dr. Agamennone's address is "Observatoire Impériale Météorologique, Constantinople (Pera)."

That one of the finest seismic regions of the globe should at last attract thc organised study it deserves, and that the initiation of the requisite observations should have fallen into hands so experienced and capable, will be matters of gratification to those who are interested in the progress of seismology. No less desirable would it be that all the results of such observations should be contained in the pages of a single journal, and Dr. Agamennone's publication of a monthly seismic bulletin, of which the first two numbers have already been issued, is an additional reason for the concentration of records from the different countries concerned in the Turkish Office.

Birmingham, April 19.

Charles Davison.

Figure 8. Charles Davison's paper in Nature related to the establishment of the Earthquake Department (Davison, 1895).

the entire district within and bordering the eastern end of the Mediterranean.

\subsubsection{Government meteorological organization: Kuvva-I Havaiye Mufettisligi}

During the World War I, the Ottoman Empire with its allied German government founded a meteorological organization called "Kuvva-I Havaiye Mufettisligi Rasat-I Havaiye Mudurlugu" in Kuruçeşme (Istanbul) on August 1915. Prof. Weikman was charged with this mission (Atabay and Aytac, 2002). Ludwif Weikman (1882-1961) was a German geophysicist, meteorologist and university lecturer. He studied physics and astronomy at the Ludwig Maximilian University of Munich. In October 1915, as German Military Meteorology Service Head, he travelled to Istanbul. He was head of the Turkish Meteorology Service from 1915 to 1918. The gained scientific experience and data there helped him write a habilitation thesis (Air Pressures and Winds in the Eastern Mediterranean) at the Ludwig Maximilian University of Munich in 1922. In 1923 Weikman was named head of the Department of Geophysics. Ludwig Weikman came to Istanbul with approximately 60 experts of meteorology to establish the meteorological stations in the Ottoman Empire's lands. Furthermore Turkish army officers were selected to help found the stations. Turkish officials were charged 
with Rasat-I Havaiye Mufettisligi (Air Observation Inspectorate) and were trained in meteorology. After the training, the army officers began to work in Edirne (Adrinapole), Gelibolu (Gallipoli), Izmir (Symrna), Sevdikoy (Sevdikoi), Zonguldak (Sunguldak), Sinop (Sinope), Ankara (Angora), Eskişehir (Eskiscehir), Konya (Konia), Sivas (Siwas), Diyarbakır (Diarbekir), Buurman (Lebanon), Beyrut (Beirut), Kudüs (Jerusalem) and Mosul (Mosull) in the meteorological stations. There are many pieces of meteorological equipments such as barometers, barographs, psychrometers, thermographs, hydrographs, pluviometers and anemometers. Furthermore wind measurements were carried out up to $6000 \mathrm{~m}$ in Vaniköy (Istanbul), Edirne, Gelibolu, Sevdikoy, Adana and Jerusalem. Measurements were carried out three times a day (morning at 07:00, afternoon at 14:00 and evening at 21:00 in the local time). Wind measurements were made once a day. Obtained pressure data were compared with the data of the Berlin meteorological station. Furthermore weather forecasting was presented to the railway directorate via post, phone and telegram.

\subsubsection{Meteorological studies and education at the Halkalı School of Agriculture}

Innovation efforts have been made in many areas during the Tanzimat era as well as in agriculture to improve agricultural production. The first step in this effort was the establishment of a school of agriculture. In 1891 the Halkalı School of Agriculture was established as the first school of its kind (Demirel and Doğanay, 2011). In this school there are meteorology lectures among other lectures. Furthermore, in this institution many meteorological observations were carried out, and these observations were published in their own journal, Halkali Ziraat Mektebi Alisi Mecmuasi. One of the aims of this journal is to publish the meteorological tables (Kadıoğlu, 2002). The weather conditions were published as tables in this journal. In the tables there are observations such as temperature, moisture and rainy days. Furthermore in this institution, there were meteorology lectures (named "Ilim-i Alaim Cevviye") (Cesme, 2004).

\section{Some results and discussion}

The physical earth and related areas in the Ottoman Empire as a scientific and educational curiosity can be seen in the 18th century with the opening of military schools in the Western style. Geography and related subjects were used especially in the field of cartography in the Naval Academy and Military Academy (Mühendishane-i Bahri Hümayun and Mühendishane-i Berri Hümayun) (Akyol, 1943). Developments in geography, which started in the military field, were also seen in civilian services after Tanzimat. Geography as a science continued its development with modern civil schools affiliated with the Western-style Ministry of Education, which opened after Tanzimat. There was some progress during the Constitutional Era (1908-1923). Beyond the aim of geography for military fields, there were studies of geography that facilitated civil life and targeted civil life during this period. For example, after Tanzimat, the meteorology building, which was established in Parmakkapı, Beyoğlu (as Rasathane-i Amire), reached its observatory purpose and moved to its building in Vaniköy as Kandilli Observatory during this period.

As Kucuk (2020) points out, science in Istanbul during this period is called practical naturalism. It is seen that many earth science books published in the Ottoman Empire are titled Arziyyat ve Madeniyyat (Mineralogy and Geology). This is evidence that geology is not only seen as a pure area but also includes practical purposes in mining activities (for example Zonguldak coal basin). There are earthquake issues in some geology books and individual books on earthquake studies. There is some attempt to found the Earthquake Department in the observatory. These issues can be considered as practical naturalism. Personal interests and/or institutionalization (such as in the observatory) in magnetic compass measurements and meteorological observations can also be evaluated within the same context.

Also, as another factor, the Ottoman intellectuals, along with Tanzimat (reorganization), were interested in all branches of science, which may have caused or triggered an interest in subjects related to the earth. In almost every field, the Tanzimat period led to a significant paradigm shift in the Ottoman Empire both intellectually and structurally.

The new developments in the industrial field, which started in the UK at the end of the 18th century, enabled the need and use of minerals. The most important factor for this is steam machines. The main energy source for steam machines was coal. For this reason, the spread of shipping and railways greatly developed and expanded mining. An important development at the beginning of the 19th century was geological mapping. It brought great economic benefits. The mineral types in the underground layers were determined and started to be used according to needs. There is an interesting relationship between pure science and economic and social needs. For example, an oil field was discovered in the 1920s by geophysical research. Later, more investments were made in geophysical research, and later more oil deposits were discovered. More oil led to more geophysical research. It was discovered that there is a feedback relationship between pure science and economics.

There are also international activities by foreign researchers to geologize in Ottoman geographies. These activities may be grouped into three categories:

1. individual-curiosity-based - independent - activities (many of them from naive scientists)

2. activities arising from relations between the Ottoman government and other states (such as Austrian military meteorology and French observatories in France and other counties) 
3. activities related to a colonial or commercial desire to exploit natural resources (for example, French and Italian companies in the Zonguldak coal basin).

Data availability. Data used in this paper are listed in the references cited throughout.

Competing interests. The author declares that there is no conflict of interest.

Special issue statement. This article is part of the special issue "History of geophysical institutes and observatories". It is not associated with a conference.

Acknowledgements. This study was carried out in the Department of the History of Science at Harvard University when the author was a visiting scholar, in the years of 2018 and 2019. I would like to thank Naomi Oreskes who was my academic sponsor.

Financial support. The study was supported by the research unit of İstanbul University (project no. FUA-2016-20557) and a TÜBITAK (The Scientific and Technical Council of Turkey) grant (2017).

Review statement. This paper was edited by Kristian Schlegel and reviewed by Okan Tezel and two anonymous referees.

\section{References}

Adams, F. D.: The Birth and Development of the Geological Sciences, Dower, New York, 1954.

Ahmad, S. M. and Baipakov, K.: Geodesy, Geology, Geography and Chartography, The Silk Route accros Central Asia, in: History of civilizations of central Asia, edited by: Asimov, M., and Bosworth, C., Vol. IV, Unesco Publishing, Delhi, 2000.

Akasoy, A.: Islamic attitudes to disasters in the Middle Ages: A comparison of earthquakes and plagues, Mediev. Hist. J., 10, 387-410, 2006.

Akın, L.: İlk Müstakil Deprem Kitabı: Risâle-İ Zelzele, İstanbul Üniversitesi Edebiyat Fakültesi Türk Dili ve Edebiyatı Dergisi, 44, 1-81, 2012.

Akyol, I. H.: Tanzimat devrinde bizde Cografya ve Jeoloji, Maarif Matbaasi, Ankara, 1940.

And, M.: Minyatürlerle Osmanl1-İslâm mitologyası, Yap1 KrediYayınları, Istanbul, 2018.

Al-Ravi, M. M.: Earth Science, in: The Oxford Encyclopedia of Philosophy, Science, and Technology in Islam, edited by: Kalin, I., Oxford University Press, USA, 2014.

Arnot, R.: The Sufistic Quatrains of Omar Khayyam, Wiley, New York, 1908.
Arslantaş, N.: II. Abdülhamid zamanında kaleme alınan bir deprem risalesi: Resul Mesti Efendi'nin Siper-i Zelzele'si [paratremblements de terre], Marmara Üniversitesi İlahiyat Fakültesi Dergisi, 33, 129-168, 2007.

Atabay, M. and Aytac, M.: Birinci dünya savaşısırasında Osmanlı İmparatorluğu topraklarında Almanların kurduğu askeri meteoroloji örgütü ve buna ait rapor, DMI Yayinlari, Ankara, 2002.

Baffioni, C.: The Causes and Features of Earthquakes in Avicenna and Fakhr al-Dīn al-Rāzī, Eur. Rev., 19, 355-366, 2011.

Bahadir, O.: Karl Terzaghi'ni Hamdi Peynircioglu'na Iki Mektucu, Bilim Tarihi Dergisi, Sayi, 4, 15-16, 1998.

Bakar, O.: Science, in: History of Islamic philosophy, edited by: Nasr, S. H. and Leaman, O., Routledge, UK, 1996.

Bein, A.: The Istanbul earthquake of 1894 and science in the late Ottoman Empire, Middle Eastern Stud., 44, 909-924, 2008.

Bekiryazıcı, E.: Hikmetül İşrak, Işrak Felsefesi (Şihabüddin EsSühreverdi), Türkiye Yazma Eserleri Kurumu Yayınları, No. 61, İstanbul, 2015.

Benois, C.: Two observatories in Istanbul: from Late Ottoman Empire to Young Turkish Republic, in: Cultural Heritage of Astronomical Observatories: From Classical Astronomy to Modern Astrophysics, 114-119, Icamos, Monuments and Sites, Berlin, 2009.

Berberian, M.: Earthquakes and coseismic surface faulting on the Iranian Plateau, Elsevier, Amsterdam, 2014.

Berman, M.: All That Is Solid Melts Into Air: The Experience of Modernity, Verso., London and Brooklyn, ISBN 978-1-84467644-6, 2010.

Burçak, B.: Modernization, Science and Engineering in the Early Nineteenth Century Ottoman Empire, Middle Eastern Stud., 44, 69-83, 2008.

Campanini, M.: An Introduction to Islamic Philosophy, translated by: Higgit, C., Edinburgh Univ. Press, 2004.

Casagrande, A.: Karl Terzaghi - his life and achievements, From theory to practice in soil mechanics, Selections from the writings of Karl Terzaghi, 3-21, Wiley, New York, 1960.

Çeşme, V.: Halkalı Ziraat Mektebi: Eğitimi, eğitimci kadrosu, örnek çiftliği ve yayınları, Osmanlı Bilimi Araştırmaları, 16, 73-99, 2014.

Cevikel, N.: The concept of science in Mevzu at ul Ulum of Taskopruluzade Ahmed bin Mustafa (1495-1561), Gazi Akademik Bakis, 3, 177-189, 2010.

Dampier, W.: A history of science and its relations with philosophy and religion, Cambridge University Press, UK, 1961.

Daud, M. N. W.: The concept of knowledge in Islam and its implications for education in a developing country, Mansel Pub., London, 1989.

Davison, C.: The study of earthquakes in south-east of Europe, Nature, 52, p. 4, 1895.

Demirel, M. and Doğanay, F.: Osmanli'da ziraat eğitimi: halkali ziraat mektebi, Social Sciences Review of the Faculty of Sciences \& Letters University of Uludag/Fen Edebiyat Fakültesi Sosyal Bilimler Dergisi, 12, 2011.

Dizer, M.: Meteorology in Turkey, Journal of History of Science of Turkey, 21, 3-19, 1993 (in Turkish).

Erdogan, A.: Perception of modern science in Tanzimat period, Sosyoloji Dergisi, 3, 1-31, 2013.

Erguvanl, K.: Turkiyede Jeoloji Konusunda ilk yayinlar, Yeryuvari ve Insan Dergisi, 5-13, 1978. 
Ethe, H.: Zakarija Ben Muhammad Ben Mahmud el-Kazwini's: Kosmographie. Nach der Wüstenfeldschen Textausgabe aus dem Arabischen zum ersten Male vollständig übersetzt (Die Wunder der Schöpfung), Fues's Verlag, Leibzich, 1868 (in German).

Fakhry, M.: A history of Islamic philosophy, Columbia University Press, USA, 1983.

Fettahoglu, K.: Rasathane-I Amirenin Kurulus ve Faaliyetleri, MSc Thesis, Marmara Universitesi, Istanbul, 2002.

Foucault, M.: Discipline and Punish: The Birth of the Prison, translated by: Sheridan, A., Vintage Books, New York and Toronto, 1995.

Gautier, T.: Position geographique determine, en 1816, 1817, 1818, das le mere Medirerranean dans Adriatic l"Archipel, An Merit et Colon, France, 1820 (in French).

Gautier, T.: Seconde compagne hidrographique sur le cotes de l'Asiea Mineute, Mere Noire, Depor General d La Mer medit, Mere Marmara, 1822.

Greenham, P.: How scientific was Islamic science? A Case study in the alchemy of al-Razi, in: Science and Religion: East and West, edited by: Fehige, Y., Routledge, UK, 2016.

Guidoboni, E.: Earthquakes, in: Theories from antiquity to 1600 , edited by: Good, G. A., Vol. 1, Sciences of the Earth' Garland Publishing, New York, 1998.

Gunergun, F.: Salih Zeki ve astronomi: Rasathane-i Amire Müdürlüğü'nden 1914 tam güneş tutulmasına, Osmanlı Bilimi Araştırmaları, cilt VII, sayı 1, (Salih Zeki Özel Sayısı), 97-121, 2005.

Gungor, Ö.: The religion of Ancient Turks, in: The Turks, Encylopedia, Vol. 1, edited by: Guzel, H. C., Oguz, C. C., Karatay, O., Yeni Turkiye Publications, Ankara, 2012.

Hagen, G.: The order of knowledge, the knowledge of order: Intellectual life, in: The Cambridge History of Turkey, edited by: Faroqhi, S. N. and Fleet, K., 407-456, Cambridge University Press, UK, 2012.

Hamarat, Z.: Believe and practices about the fall of the Cemre, Trakya University Edebiyat Faultesi Dergisi, 2, 165-200, 2012.

Henry, J.: A short history of scientific thought, Palgrave Macmillian, New York, 2012.

Hirshler, K.: Earthquakes, in: Medieval Islamic civilization: an encyclopedia, edited by: Meri, J. W., Routledge, UK, 2006.

Holmyard, D. C. and Mandeville, E. J.: Avicennae de congelatione et conglutinatione lapidum, being sections of the Kitab al-Shifa (the Latin and Arabic texts edited with an English translation of the latter and with critical notes), Libraire Oriéntaliste Geuthner, Paris, 1927.

İhsanoğlu, E.: Ottoman Science, in: Encyclopedia of History of Science, Technology and Medicine in Non-Western Cultures, edited by: Selin, H., Kuwer Academic Publishers, Dortrecht, 1997.

İhsanoğlu, E.: Science, Technology and Learning in The Ottoman Impire: Western influence, local institutions and transfer of knowledge, Asgate publishing Limited, London, 2004.

İhsanoğlu, E.: Institutionalisation of Science in the Medreses of preOttoman and Ottoman Turkey, Turkish Studies in the History and Philosophy if Science, 265-283, Springer, Dordrecht, 2005.

İhsanoğlu, I. and Ayduz, S.: Ottoman Science and Education in the Modern age, in: The Turks, Encylopedia, Vol. 4, edited by: Guzel, H. C., Oguz, C. C., Karatay, O., Yeni Türkiye Publications, Ankara, 2002.
İnalcık, H.: The Ottoman Empire: The Classical Age, translated by: Itzkowitz, N. and Imber, C., Weidenfeld and Nicolson, London, 121 pp., 1973.

Irmak, S.: Tıp Tarihi: İbrahim Hakkı (1703-1780) ve Pozitif İlimler, İ̈̈ Tıp Fakültesi Mecmuası, XXXVI, İstanbul, 1973.

Iqbal, M.: Science and Islam, Greenwood Publishing Group, UK, 2007.

Ishakoglu, S.: 1900-1946 Yillari Arasinda, Darülfünun ve Istanbul Üniversitesi Fen Fakültesi'nde Matematik ve Fen Bilimleri Egitimi. Osmanli Bilimi Arastirmalari, Istanbul, 227-283, 1995.

Izgi, C.: Osmanli medreselerinde Ilim, Vol. 2, Iz Yayincilik, Istanbul, 1997.

Kadığlu, S.: Halkalı Ziraat Mekteb-i Alisi Mecmuası Üzerine Bir İnceleme, Osmanlı Bilimi Araştırmaları, 4, 99-118, 2002.

Kahya, E.: Science among the Ancient Turks, in: The Turks, Encylopedia, Vol. 1, edited by: Guzel, H. C., Oguz, C. C., Karatay, O., Yeni Türkiye Publications, Ankara, 2002a.

Kahya, E.: Scientific works among Seljuk Turks, in: The Turks, Encylopedia, Vol. 1, edited by: Guzel, H. C., Oguz, C. C., and Karatay, O., Yeni Türkiye Publications, Ankara, 2002b.

Kahya, E. and Topdemir, H. G.: The contribution of Turks to the scientific works in the medieval Islamic world, in: The Turks, Encylopedia, Vol. 2, edited by: Guzel, H. C., Oguz, C. C., and Karatay, O., Yeni Türkiye Publications, Ankara, 2002.

Kant, I.: Kant: Natural Sciences, The Cambridge Edition of the Works of Immanuel Kant), Cambridge University Press, UK, 2015.

Kennedy, E. S.: Al-Biruni, in: Dictionary of scientific biography, edited by: Gillispie, C. C., Scribner's, New York, NY, USA, 1970.

Kepekci, D. and Ozcep, F.: Brief communication "Fasttrack earthquake risk assessment for selected urban areas in Turkey", Nat. Hazards Earth Syst. Sci., 11, 571-585, https://doi.org/10.5194/nhess-11-571-2011, 2011.

Ketin, İ.: Türkiye jeolojisine genel bir bakış, İstanbul Teknik Üniversitesi pub., Istanbul, 1983.

Kınaylı, H.: Deprem, in: İstanbul ansiklopedisi, edited by: Koçu, R. E., Cilt: 8, Koçu Yayınları, Istanbul, 1958.

Kish, G. (Ed.): A source book in geography, Harvard University Press, USA, 1978.

Küçük, H.: Science without Leisure: Practical Naturalism in Istanbul, 1660-1732, University of Pittsburgh Press, USA, 2020.

Leaman, O.: Islamic Philosophy, Polity, Cambridge, UK, 2009.

Lettinck, P. (Ed.): Aristotle's Meteorology and Its Reception in the Arab World: With an Edition and Translation of Ibn Suwār's Treatise on Meteorological Phenomena and Ibn Bājja's Commentary on the Meteorology, Vol. 10, Brill, USA, 1999.

Lettinck, P.: Metrerology, in: Medieval Islamic civilization: an encyclopedia, edited by: Meri, J. W., Routledge, UK, 2006.

Marmura, M. (translated, introduced, and annotated): al-Ghazālī: the Incoherence of the Philosophers=Tahāfut al-falāsifa, Brigham Young University Press, UK, 2000.

McPeak, W. J.: Meteorology in Islamic world, in: Encyclopedia of the History of Science. Technology, and Medicine in non western Cultures, edited by: Selin, H., Vol. 2, Springer Pub, Dortrecht, 1997.

McPeak, W. J.: Meteorological Ideas, Islam and Europe, in: Sciences of the Earth: An Encyclopedia of Events, People and Phe- 
nomena, Vol. 2, edited by: Good, G. A., Garland Publishing, New York and London, 1998.

Melville, C.: Zalzala, in: The Encyclopedia of Islam, edited by: Bearman, P. J., Bianquis, Th., Bosworth, C. E., van Donzel, E., and Heinrichs, W. P., Brill, Leiden, 2002.

Montgomery, S. L. and Kumar, A.: A history of Science in world cultures: voices of knowledge, Routledge, UK, 2015.

Nasr, S. H.: Introduction to Islamic Cosmological Doctrines, Harvard University Press, USA, 1964.

Needham, J.: Science and Civilisation in China: Volume 4, Physics and Physical Technology, Cambridge University Press, UK, 1959a.

Needham, J.: Science and civilization in China. Mathematics and the Sciences of the Heavens and the Earth, Vol. 3, Cambridge University Press, UK, 1959b.

Noyan, O. F.: Geology, in: The Oxford Encyclopedia of Philosophy, Science, and Technology in Islam, edited by: Kalin, I., Oxford University Press, USA, 2014.

Ozcep, F.: Terrestrial Magnetism in The Ottoman Empire: Documents And Measurements, Earth Sci. Hist., 37, 1-24, 2018.

Ozcep, F. and Ozcep, T.: Notes on the history of geophysics in the Ottoman Empire, Hist. Geo Space. Sci., 5, 163-174, https://doi.org/10.5194/hgss-5-163-2014, 2014.

Ozdalga, E.: Introduction, in: Late Ottoman Society: The Intellectual Legacy, edited by: Özdalga, E., Psychology Press, UK, 2005.

Ozudogru, K.: Modern zemin mekaniğinin kuruluşu: Karl Terzaghi ve Türkiye, İTÜDERGİSİ/d 2.5, ITU Publications, Istanbul, 2010.

Pakalın, M. Z.: Osmanlıtarih deyimleri ve terimleri sözlüğü (Vol. 1), Milli Eğitim Basımevi, 1993.

Sarton, G.: Introduction to the History of Science, Vol. 1, From Homer to Omar Khayyam, Carnegie Institution of Washington, by the Williams and Wilkins Company, Baltimore, 1927.

Sayili, A. M.: Al Qarāfī and His Explanation of the Rainbow, Isis, 32, 16-26, 1940.

Şengör, C.: Osmanli'nin Ilk Jeoloji Kitabi ve Osmanli'da Jeolojinin Durumu Hakkinda Öğrettikleri, Osmanlı Bilimi Araştırmaları, 11, 119-158, 2011.
Sersen, W. J.: Arab meteorology from pre-islamic times to the thirteenth century AD, Doctoral dissertation, School of Oriental and African Studies (University of London), 1976.

Sesiano, J.: Al-Khawarizmi, in: Encyclopedia of the History of Science, Technology, and Medicine in non western Cultures, edited by: Selin, H., Vol. 2, Springer Pub, Dortrecht, 1997.

Shefer-Mossensohn, S.: Science among the Ottomans The Cultural Creation and Exchange of Knowledge, University of Texas Press, 2015.

Straughn, I. B.: Climate, Theories Of Medieval Islamic Civilisation: An Encyclopaedia, 1, 157-158, 2006.

Taglia, S.: Intellectuals and Reform in the Ottoman Empire: The Young Turks on the Challenges of Modernity, Routledge, UK, 2015.

Terzaghi, K.: Foundation problems and laboratory research, Eng. News-Rec., 87, 77-78, 1921.

Toelle, H.: Earth, in: Encyclopedia of the Qur'an, Vols. 1-6, edited by: McAuliffe, J. D., Brill, the Netherlands, Leiden, 2001.

Topdemir, G.: Salih Zeki, in: The Biographical Encyclopedia of Astronomers, edited by: Hockey, T., Trimble, V., Williams, T. R., Bracher, K., Jarrell, R. A., Marché II, J. D., Ragep, F. J., Palmeri, J., and Bolt, M., Springer Science Business Media, LLC, 10071008, 2007.

Unver, S.: Willian Lane in Istanbul'da meteoroloji calismalari uzerine, Kandilli Rasathanesi Bilim Tarihi Yayinlari, No. 5, Istanbul, 1973.

Uysal, E., Avcu, A., Demirkol, M., Gökdağ, K., and Aliyev, E.: Ihvan-1 Safa Risaleleri, Cilt2, AyrıntıYayınları, Istanbul, 2013.

Viquesnel, A.: Voyage dans la Turquie d'Europe, Paris, 1868.

Yalcinkaya, M. A.: Their science, our values: Science, state and society in the 19th century Ottoman Empire, University of California, San Diego, 2010.

Yücesoy, H.: Translation as Self-Consciousness: Ancient Sciences, Antediluvian Wisdom, and the Abbāsid Translation Movement, J. World Hist., 20, 523-557, 2009. 